\title{
PENGARUH ASSURANCE TERHADAP LOYALITAS PELANGGAN CORPORATE TIKET MASKAPAI PENERBANGAN DOMESTIK PT. INTERLINK TOURS \& TRAVEL BANDUNG
}

(Survey Kepada Pelanggan Corporate Tiket Maskapai Penerbangan Domestik PT. Interlink Tours and Travel Bandung)

\author{
Desi Aryanti \\ Eeng Ahman \\ Dewi Pancawati \\ Manajemen Pemasaran Pariwisata FPIPS UPI
}

\begin{abstract}
Travel and tourism in the world is a milestone for the global economy industry today. Tourism is currently standing strong in almost all countries as an industry in their respective countries, including Indonesia. One of the important tourism industry in the implementation of tourism is travel services as tourist facilities required to meet travel. One of the travel services required by tourists is a travel agency. Many travel agents established in the provinces where people often travel potentially that West Java especially in Bandung. In 2011 the number of places of business travels are in Bandung as many as 218. One of the largest travel agency in Bandung is PT. Interlink Tours and Travel. In terms of sales, PT. Interlink Tours and Travel rely more on domestic airline tickets customers in large numbers and repeatedly. In 2011 customers of PT. Interlink Tours and Travel have decreased loyalty. One way PT. Interlink Tours and Travel do to enhance customer loyalty to an airline ticket sales in accordance with the target is to provide quality service to customers with a focus on communication, credibility, security, competence and courtesy. In marketing this is called assurance. Assurance theory used is the theory of the Parasuraman in Ririn Tri Ratnasari (2011:109) and the theory of customer loyalty using the theory Baloglu (2002). The population in this study is the corporate customers of domestic airline tickets in PT. Interlink Tours and Travel Bandung. Sampling technique used is saturated sampling and data analysis technique used is multiple regression. Overview of research on assurance and customer loyalty is in a good position. The results showed simultaneous assurance effect on customer loyalty. However, partially only competence sub variables that influents the loyalty, while the other four sub variables, namely communication, credibility, security and courtesy are no effect on customer loyalty.
\end{abstract}

Keywords: Assurance, Customer Loyalty.

I. PENDAHULUAN

\subsection{Latar Belakang}

Perjalanan dan pariwisata dunia pada tahun 2012 ditetapkan sebagai tahun tonggak untuk industri ekonomi global yang diperkirakan akan melewati \$2 triliun GDP dan 100 juta pekerjaan (www.wttc.org, diakses pada tanggal 3 April 2012). Menurut penelitian oleh World Travel \& Tourism Council (WTTC), perjalanan global dan industri pariwisata akan tumbuh sebesar 2,8\% pada tahun 2012, sedikit lebih cepat daripada tingkat pertumbuhan ekonomi global yang diprediksi menjadi 2,5\%. Tingkat pertumbuhan menunjukkan industri pariwisata diharapkan secara langsung berkontribusi \$ 2 triliun untuk perekonomian global dan mempertahankan beberapa 100.300 .000

pekerjaan. Pariwisata sekarang ini berdiri kokoh di hampir semua negara sebagai suatu industri di negara masing-masing termasuk Indonesia. Pengembangan pariwisata dapat mempercepat pertumbuhan ekonomi dalam pembangunan suatu negara. Pariwisata diharapkan menjadi primadona penghasil devisa negara yang dibutuhkan dalam pembangunan yang berkelanjutan.

Pariwisata Indonesia yang kaya akan objek wisatanya telah mampu memberikan dampak berganda (multipler effect) pada peningkatan lapangan pekerjaan. Pariwisata menyediakan pekerjaan bagi karyawan hotel, pemandu wisata, penghibur, karyawan restoran, dan pekerja dalam bidang perjalanan 
lainnya. Sektor pariwisata Indonesia semakin lama semakin berkembang. Hal ini dapat dilihat dari peningkatan jumlah wisatawan dari tahun 2007 sampai tahun 2011 yang mengalami peningkatan berikut Tabel 1.1 mengenai perkembangan wisatawan mancanegara tahun 2007-2012.

TABEL1.1

STATISTIK PERKEMBANGAN WISATAWAN DI INDONESIA 2007-2012

\begin{tabular}{|c|c|c|c|}
\hline \multirow{2}{*}{ No } & \multirow{2}{*}{ Tahun } & \multicolumn{2}{|c|}{$\begin{array}{c}\text { Jumlah Kunjungan } \\
\text { Wisatawan }\end{array}$} \\
\cline { 3 - 4 } & & Wisman & Wisnas \\
\hline 1 & 2007 & $5,505,759$ & $5,158,441$ \\
\hline 2 & 2008 & $6,234,497$ & $4,996,594$ \\
\hline 3 & 2009 & $6,323,730$ & $5,053,269$ \\
\hline 4 & 2010 & $7,002,944$ & $6,235,606$ \\
\hline 5 & 2011 & $7,649,731$ & $6,594,231$ \\
\hline 6 & 2012 (Jan) & 652,692 & 517,608 \\
\hline
\end{tabular}

Sumber: www.budpar.go.id, 2012.

Perkembangan jumlah kunjungan wisatawan baik mancanegara maupun nasional mengalami fluktuasi dari tahun 2007 sampai 2011. Pertumbuhan yang cukup besar terjadi pada tahu 2011, dari target wisatawan mancanegara 7,1 juta orang, Indonesia mampu mendatangkan hampir 7,6 juta pada tahun 2011 dimana prosentse perubahan jumlah wisman sebesar $8,5 \%$ dibandingkan tahun 2010. Hal ini menunjukkan pencapaian pada tahun 2011 memenuhi target nasional kunjungan wisatawan mancanegara ke Indonesia. Perkembangan wisatawan nasional mengalami penurunan pada tahun 2008 sebesar 3,2 \%. Namun pada tahun 2011 kunjungan wisatawan nasional mengalami peningkatan sebesar 5,4 \%. Hal ini menunjukkan minat wisatawan nusantara melakukan perjalanan domestik cukup tinggi.

Jumlah persediaan barang-barang dan pelayanan jasa-jasa memungkinkan adanya perjalanan dan penginapan bagi para wisatawan. Industri pariwisata secara ekonomis menggantungkan 100\% kepada kegiatan pariwisata. Salah satu perusahaan jasa pariwisata yang mendukung para wisatawan dalam memenuhi kebutuhannya adalah perusahaan perjalanan. Akomodasi merupakan salah satu kebutuhan yang tidak dapat dipisahkan dari wisatawan dalam melakukan kegiatan pariwisata khususnya bagi wisatawan yang melakukan perjalanan untuk tujuan konferensi, seminar, bisnis, dan kegiatan lain. Akomodasi adalah fasilitas penginapan bagi orang yang sedang bepergian (www.wikipedia.org, diakses pada tanggal 3 April 2012). Perusahaan perjalanan ikut berperan penting dalam menyediakan akomodasi bagi wisatawan di suatu daerah tujuan. Berdasarkan UU No. 10 Tahun 2009 Tentang Kepariwisataan menjelaskan bahwa usaha jasa perjalanan wisata adalah jasa transportasi wisata dan jasa perjalanan wisata. Jasa perjalanan wisata meliputi pemesanan tiket, pemesanan hotel, dan penyelenggaraan perjalanan pariwisata. Perusahaan perjalanan wisata yang ada di Indonesia terdapat dua kategori, yaitu biro perjalanan dan agen perjalanan. Seiring berkembangnya usaha Jasa Perjalanan Indonesia yang mengalami pertumbuhan berdampak pada jumlah usaha Biro Perjalanan Wisata dan Agen Perjalanan Wisata yang ada di Indonesia. Hal tersebut dapat dilihat pada Tabel 1.2. 
TABEL 1.2

PERKEMBANGAN USAHA JASA PERJALANAN WISATA BERSKALA MENENGAH DAN BESAR TAHUN 2007 - 2009

\begin{tabular}{|c|c|c|c|c|c|c|c|c|}
\hline \multirow{3}{*}{$\begin{array}{c}\text { TAH } \\
\text { UN }\end{array}$} & \multicolumn{3}{|c|}{$\begin{array}{c}\text { BPW (BIRO } \\
\text { PERJALANAN WISATA) }\end{array}$} & \multicolumn{3}{|c|}{$\begin{array}{c}\text { APW (AGEN PERJALANAN } \\
\text { WISATA) }\end{array}$} & \multirow{2}{*}{\multicolumn{2}{|c|}{$\begin{array}{c}\text { USAHA JASA } \\
\text { PERJALAN } \\
\text { WISATA } \\
\text { (BPW+APW) }\end{array}$}} \\
\hline & \multicolumn{2}{|c|}{$\begin{array}{c}\text { USAHA / } \\
\text { PERUSAHAAN }\end{array}$} & \multirow{2}{*}{$\begin{array}{c}\text { RATA- } \\
\text { RATA } \\
\text { TENAGA } \\
\text { KERJA }\end{array}$} & \multicolumn{2}{|c|}{$\begin{array}{c}\text { USAHA / } \\
\text { PERUSAHAAN }\end{array}$} & \multirow{2}{*}{$\begin{array}{c}\text { RATA- } \\
\text { RATA } \\
\text { TENAGA } \\
\text { KERJA }\end{array}$} & & \\
\hline & $\begin{array}{l}\text { JUM } \\
\text { LAH }\end{array}$ & $\begin{array}{l}\text { PERTU } \\
\text { MBUH } \\
\text { AN }(\%)\end{array}$ & & $\begin{array}{l}\text { JUM } \\
\text { LAH }\end{array}$ & $\begin{array}{c}\text { PERTU } \\
\text { MBUHA } \\
\text { N }(\%)\end{array}$ & & $\begin{array}{c}\text { JUML } \\
\text { AH }\end{array}$ & $\begin{array}{c}\text { PERTU } \\
\text { MBUHA } \\
\text { N }(\%)\end{array}$ \\
\hline 2007 & 655 & - & 11,00 & 1.159 & - & 9,00 & 1.814 & - \\
\hline 2008 & 815 & 24,43 & 12,05 & 1.893 & 63,33 & 7,57 & 2.708 & 49.28 \\
\hline 2009 & 952 & 16,81 & 12,35 & 1,803 & $-4,75$ & 6,51 & 2.755 & 1,74 \\
\hline 2010 & 1,116 & 17,23 & 11,00 & 1,917 & 6,32 & 6,00 & 3,003 & 10,09 \\
\hline
\end{tabular}

Sumber: Budpar.go.id, 2012

Jumlah Biro Perjalanan (BPW) meningkat dari tahun ke tahun pada tahun 2010 meningkat sebesar 17,23\% dan Agen Perjalanan Wisata (APW) pun meningkat pada tahun 2010 sebesar 6,00\%. Jumlah BPW pada tahun 2010 meningkat dari tahun 2009 yaitu dari 952 perusahaan menjadi 1,116 perusahaan. Jumlah APW pada tahun 2010 pun meningkat dari tahun 2009 yaitu dari 1,803 perusahaan menjadi 1,917 perusahaan. Hal ini menunjukkan bahwa kebutuhan akan perjalanan wisata semakin tinggi dan beragam sehingga banyak berdiri perusahaan perjalanan wisata yang menawarkan jasanya untuk memenuhi keinginan wisatawan.

Indonesia terdiri dari 33 provinsi, diantaranya adalah Provinsi Jawa Barat yang memiliki kekayaan budaya dan pariwisata yang beraneka ragam. Beberapa diantaranya memiliki kualitas dan daya tarik yang tinggi. Sumber daya kebudayaan yang dimiliki, seperti bahasa, sastra, aksara daerah, kesenian, kepurbakalaan, kesejarahan, nilai tradisional dan museum masih berkembang, serta keberadaannya dapat diandalkan untuk pembangunan jatidiri bangsa. Sektor pariwisata merupakan salah satu usaha inti dari pembangunan ekonomi regional Jawa Barat. Indikator keberhasilan pengembangan pariwisata suatu daerah seringkali diukur dari peningkatan jumlah wisatawan yang berkunjung. Indikator lainnya dalam pengembangan pariwisata adalah dengan peningkatan daerah dari sektor pariwisata. Kedua indikator tersebut merupakan upaya dalam rangka optimalisasi keberhasilan di bidang kepariwisataan sebagai pemicu pengembangan ekonomi daerah. Jumlah wisatawan baik mancanegara maupun nusantara yang berkunjung ke Jawa Barat mengalami fluktuasi dari tahun ke tahun, seperti yang dapat dilihat pada Tabel 1.3 dibawah ini 


\begin{tabular}{|c|c|c|c|c|c|c|c|c|}
\hline \multirow{4}{*}{$\begin{array}{l}\mathrm{N} \\
\mathrm{o}\end{array}$} & \multicolumn{8}{|c|}{$\begin{array}{c}\text { TABEL } 1.3 \\
\text { DATA KUNJUNGAN WISATAWAN KE AKOMODASI DAN } \\
\text { OBJEK WISATA DI PROVINSI JAWA BARAT TAHUN 2006-2010 }\end{array}$} \\
\hline & \multirow{3}{*}{ Tahun } & \multirow{2}{*}{\multicolumn{2}{|c|}{$\begin{array}{c}\text { Jumlah Wisatawan } \\
\text { Ke Akomodasi }\end{array}$}} & \multirow{2}{*}{\multicolumn{2}{|c|}{$\begin{array}{c}\text { Jumlah Wisatawan } \\
\text { Ke Objek Wisata }\end{array}$}} & \multirow{3}{*}{$\begin{array}{l}\text { Jumlah } \\
\text { Wisman }\end{array}$} & \multirow{3}{*}{$\begin{array}{l}\text { Jumlah } \\
\text { Wisnus }\end{array}$} & \multirow{3}{*}{ Total } \\
\hline & & & & & & & & \\
\hline & & Wisman & Wisnus & Wisman & Wisnus & & & \\
\hline 1 & 2006 & 217.838 & 5.774 .581 & 227.068 & 23.859 .547 & 444.906 & 29.634 .128 & 30.079 .034 \\
\hline 2 & 2007 & 256.171 & 5.798 .456 & 338.956 & 23.782 .302 & 595.127 & 29.580 .758 & 30.175 .885 \\
\hline 3 & 2008 & 424.500 & 6.347 .298 & 330.369 & 26.287 .031 & 754.869 & 32.634 .329 & 33.389 .198 \\
\hline 4 & 2009 & 504.218 & 6.761 .190 & 678.829 & 28.334 .497 & $\begin{array}{r}1.183 .04 \\
7\end{array}$ & 35.095 .687 & 36.278 .734 \\
\hline \multirow[t]{2}{*}{5} & 2010 & 498.163 & 8.976 .683 & 720.683 & 25.066 .687 & $\begin{array}{r}1.218 .84 \\
6\end{array}$ & 34.043 .370 & 35.262 .216 \\
\hline & $\begin{array}{l}\text { Jumla } \\
\mathrm{h}\end{array}$ & $\begin{array}{r}1.900 .89 \\
0\end{array}$ & $\begin{array}{r}33.658 .20 \\
8\end{array}$ & $\begin{array}{r}2.295 .90 \\
5\end{array}$ & $\begin{array}{r}127.330 .06 \\
4\end{array}$ & $\begin{array}{r}4.196 .79 \\
5\end{array}$ & $\begin{array}{r}160.988 .27 \\
2\end{array}$ & $\begin{array}{r}165.185 .06 \\
7\end{array}$ \\
\hline
\end{tabular}

Sumber: Dinas Kebudayaan dan Pariwisata Jawa Barat, 2011

Kunjungan wisatawan baik mancanegara maupun nusantara mengalami fluktuasi dari tahun ke tahun. Dilihat dari total kunjungan wisatawan ke akomodasi dan objek wisata di Jawa Barat peningkatan terbesar terjadi pada tahun 2009 yaitu berjumlah 36.278 .734 wisatawan, sementara penurunan terjadi pada tahun 2010 sebesar $2,8 \%$ yaitu 35.262.216 wisatawan. Peningkatan yang signifikan terjadi pada kunjungan wisatawan mancanegara ke Jawa Barat yaitu sebesar 1.218.846 wisatawan, jumlah kunjungan ini melebihi target dari Dinas Kebudayaan dan Pariwisata Provinsi Jawa Barat yang menargetkan $10 \%$ dari target nasional yaitu 7.000.000 wisatawan mancanegara. Sementara penurunan tersebut terjadi pada kunjungan wisatawan nusantara yang belum mencapai target, Dinas Kebudayaan dan Pariwisata Provinsi Jawa Barat menargetkan kunjungan wisatawan domestik sebesar 40.000.000 wisatawan namun wisatawan nusantara yang berkunjung ke Jawa Barat hanya 34.043.370 wisatawan. Namun di satu sisi, jumlah wisatawan nusantara ke akomodasi mengalami peningkatan pada tahun 2010 sebesar $24,7 \%$. Peningkatan tersebut membuktikan minat wisatawan nusantara ke akomodasi cukup besar. Hal ini memberikan peluang yang besar pula pada perusahaan perjalanan untuk ikut berperan dalam memenuhi salah satu kebutuhan wisatawan dalam penyediaan akomodasi.

Dilihat dari jumlah wisatawan yang berkunjung ke Jawa Barat, hal ini dapat dijadikan pertimbangan bagi para pelaku pariwisata di Jawa Barat baik itu pemerintah, masyarakat, maupun perusahaan swasta, seperti biro perjalanan wisata untuk mengembangkan bidang kepariwisataan. Provinsi Jawa Barat merupakan provinsi yang memiliki potensi daerah tujuan wisata utama dan masyarakatnya sering melakukan perjalanan sehingga jumlah perusahaan jasa perjalanan wisata seperti biro perjalanan wisata di Jawa Barat kian bertambah. Selain itu kegiatan bisnis yang berkembang di daerah ini serta jumlah penduduk yang relatif besar juga mempengaruhi perkembangan jumlah BPW, seperti yang terlihat pada Gambar $1.1 \mathrm{di}$ bawah ini.

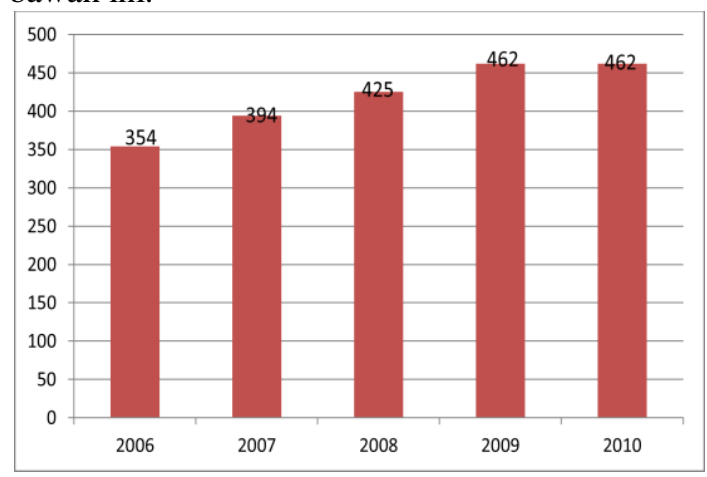

GAMBAR 1.1

PERTUMBUHAN BIRO PERJALANAN WISATA (BPW) DI PROVINSI JAWA BARAT TAHUN 2006-2010

Sumber: Dinas Kebudayaan dan Pariwisata Jawa Barat Tahun 2011 
Jumlah Biro Perjalanan Wisata (BPW) di Jawa Barat mengalami peningkatan dari tahuntahun sebelumnya. Pada tahun 2009 dan tahun 2010 BPW berjumlah 462, sebelumnya pada tahun 2008 BPW di Jawa Barat berjumlah 425. Meningkatnya jumlah BPW di Jawa Barat ini dikarenakan banyaknya wisatawan yang melakukan perjalanan sehingga munculnya peluang bagi pelaku industri pariwisata untuk memberikan pelayanan sesuai kebutuhan dan keinginan wisatawan semenjak wisatawan berangkat sampai di tempat tujuan, hingga wisatawan kembali ke rumahnya. Salah satu industri pariwisata yang dapat memberikan pelayanan terhadap wisatawan adalah biro perjalanan wisata.

Jumlah usaha perjalanan wisata di Jawa Barat ini meningkat karena dipengaruhi oleh masyarakat yang sering melakukan perjalanan dan kegiatan bisnis yang berkembang di kotakota besar di Provinsi Jawa Barat, salah satunya Kota Bandung yang merupakan kota dimana para pelaku industri pariwisata banyak mendirikan usaha perjalanan wisata.

TABEL 1.4

JUMLAH TEMPAT USAHA PERJALANAN WISATA DI KOTA BANDUNG

\begin{tabular}{|c|c|c|c|c|}
\hline Tahun & BPW & CBPW & APW & Total \\
\hline 2010 & 156 & 19 & 9 & 184 \\
\hline 2011 & 191 & 18 & 9 & 218 \\
\hline
\end{tabular}

Sumber: www.bandungtourism.com, 2011

Usaha perjalanan wisata yang ada di Bandung berkembang dengan pesat dalam kurun waktu yang singkat. Pada tahun 2010 jumlah tempat usaha jasa perjalanan wisata di Kota Bandung berjumlah 184, pada tahun 2011 jumlah tempat usaha jasa perjalanan wisata di Kota Bandung naik sebesar 18,5\% menjadi 218 seperti yang dapat dilihat pada Tabel 1.4. Keberadaan usaha perjalanan wisata sangat penting di industri pariwisata dalam hal penjualan tiket (ticket sales), pemesanan kamar hotel (hotel reservation), pengurusan dokumen perjalanan (travel document), merencanakan dan menjual paket wisata (package tour), baik dalam negeri, dari luar negeri, ke dalam negeri atau sebaliknya. Salah satu usaha perjalanan wisata yang terbesar di Kota Bandung adalah PT. Interlink Tours and Travel. PT. Interlink Tours and Travel merupakan biro perjalanan wisata cakra IV yang berdiri sejak tahun 1976.

Produk-produk utama dari PT. Interlink Tours and Travel adalah menyediakan jasa Tiket Domestik, Tiket Internasional, Tur Domestik dan Tur Internasional. Produkproduk tersebut setiap tahunnya ada yang mengalami peningkatan ada pula yang mengalami penurunan dalam penjualannya. Seperti yang dapat dilihat pada Gambar 1.2 


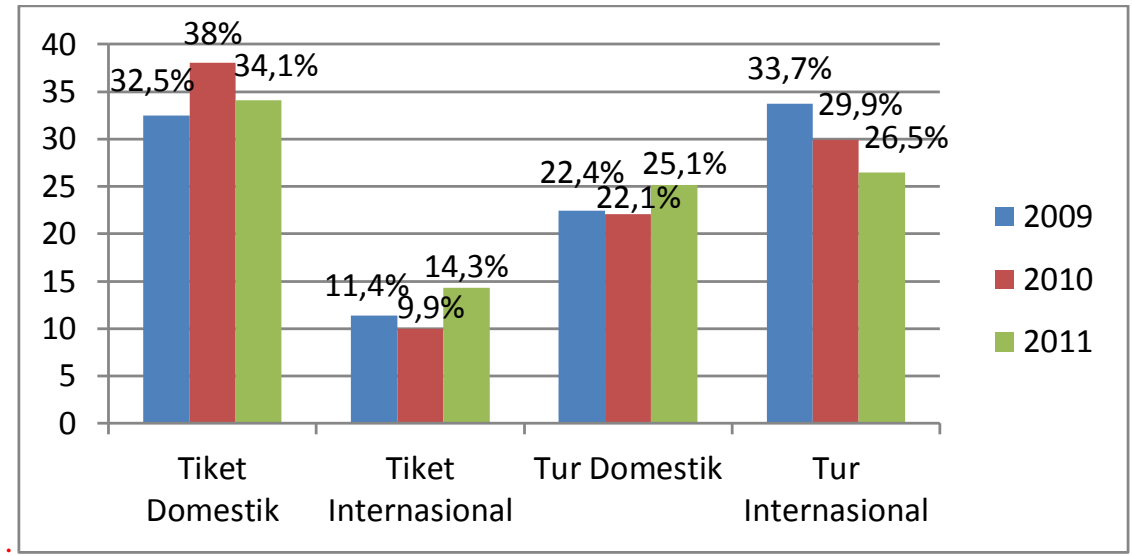

Sumber: Accounting PT.Interlink Tours and Travel Bandung, 2012

GAMBAR 1.2

PROSENTASE PROFIT PENJUALAN PRODUK UTAMA PT.INTERLINK TOURS AND TRAVEL BANDUNG

Salah satu produk yang menjadi andalan dan memberikan profit terbesar dalam penjualan pada perusahaan ini adalah tiket maskapai penerbangan domestik. "Tiket penerbangan adalah jenis produk utama hampir semua biro perjalanan", (Dennis L. Foster, 2000:54). Pelanggan PT. Interlink Tours and Travel Bandung lebih sering menggunakan jasa perusahaan ini dalam penyediaan tiket maskapai penerbangan domestik. Maka dari itu, penjualan tiket maskapai penerbangan domestik menjadi fokus utama dalam memberikan pelayanan kepada pelanggan karena dapat memberikan profit yang cukup besar bagi perusahaan. Setiap tahunnya PT. Interlink Tours and Travel Bandung sebagai salah satu biro perjalanan terbesar di Kota Bandung selalu menetapkan target dalam meningkatkan volume penjualan termasuk penjualan tiket maskapai penerbangan domestik. Seperti dilihat dalam Gambar 1.3.

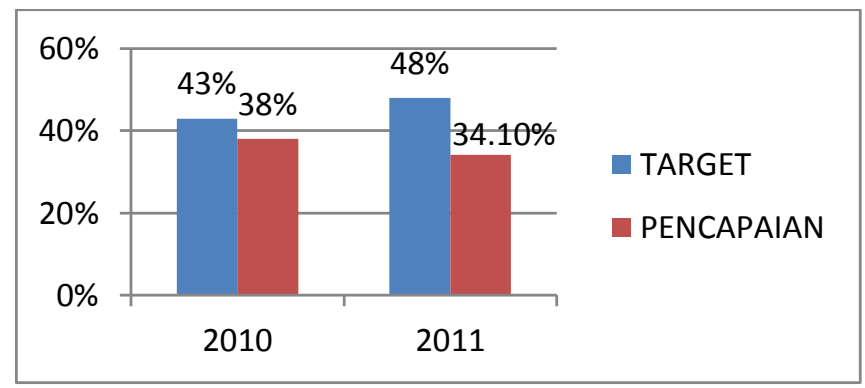

GAMBAR 1.3

PROSENTASE TARGET \& PENCAPAIAN TIKET MASKAPAI PENERBANGAN DOMESTIK 2010-2011

Sumber: Accounting PT. Interlink Tours and Travel Bandung, 2012

Berdasarkan Gambar 1.3 PT. Interlink Tours and Travel Bandung selalu menetapkantarget setiap tahunnya meningkat dari tahun sebelumnya. Namun pencapaian yang didapat belum dapat memenuhi target terutama tahun
2011. Keuntungan besar yang didapat dari penjualan tiket maskapai penerbangan domestik perusahaan ini bersumber dari pelanggan PT. Interlink Tours and Travel Bandung yang selalu membeli tiket berulangulang dalam jumlah yang banyak. 
Berikut ini grafik pelanggan dan rata-rata frekuensi menggunakan tiket maskapai penerbangan domestik PT. Interlink Tours and Travel Bandung.

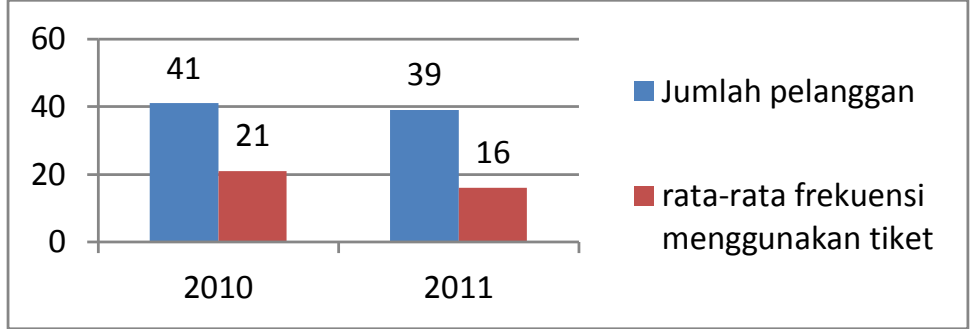

Sumber: Domestic Ticketing PT. Interlink Tours \& Travel Bandung, 2012

GAMBAR 1.4

JUMLAH PELANGGAN DAN FREKUENSI MENGGUNAKAN TIKET MASKAPAI PENERBANGAN DOMESTIK PT. INTERLINK TOURS AND TRAVEL 2010-2011

Jumlah pelanggan PT. Interlink Tours and Travel Bandung pada tahun 2011 mengalami penurunan dari tahun 2010. Pelanggan yang merupakan instansi-instansi dan agen perjalanan wisata pada tahun 2010 berjumlah 41 pelanggan, namun pada tahun 2011 jumlah pelanggannya berkurang sebesar $4,8 \%$ padahal pelanggan tersebut sudah ratarata berlangganan selama 5 tahun. Dilihat dari rata-rata frekuensi menggunakan tiket maskapai penerbangan domestik pun mengalami penurunan sebesar $23,8 \%$. Hal ini menunjukkan adanya permasalahan dimana beberapa perusahaan yang tidak lagi menggunakan jasa PT. Interlink Tours and Travel Bandung dalam penyediaan tiket maskapai penerbangan domestik dimana menunjukkan indikasi tingkat loyalitas yang menurun.

PT. Interlink Tours and Travel Bandung perlu melakukan upaya-upaya dalam hal memelihara pelanggan agar tetap loyal menggunakan jasa perusahaan ini dalam penyediaan tiket maskapai penerbangan domestik. Strategi yang dilakukan PT. Interlink Tours and Travel Bandung dalam meningkatkan loyalitas pelanggannya adalah melalui assurance, yaitu perusahaan memberikan pelayanan yang prima kepada pelanggan yang menjadi fokus utama agar dapat memberikan kualitas jasa yang dipersepsikan pelanggan sehingga menciptakan loyalitas pelanggan yang tinggi . Tujuan dari perusahaan ini adalah mendapatkan profit yang besar dari tamu yang membeli produk secara berulang-ulang khususnya tiket maskapai penerbangan domestik. Karyawan PT. Interlink Tours and Travel Bandung dituntut harus melaksanakan pelayanan yang prima kepada pelanggan dengan memiliki pengetahuan yang luas dalam menyediakan jasa perjalanan wisata, kesopansantunan dan kemampuan para pegawai perusahaan untuk meningkatkan loyalitas pelanggan kepada perusahaan. Pelayanan tersebut dalam marketing disebut dengan Assurance. Pada penelitian Lo, Osman, Ramayah \& Rahim dalam International Journal of Marketing Studies (2010) menyimpulkan "shows a significant relationship between assurance and customer loyalty". Artinya terdapat pengaruh yang signifikan antara assurance terhadap loyalitas pelanggan.

Strategi assurance yang diterapkan kepada para pelanggan yaitu, meliputi komunikasi, kredibilitas, keamanan, kemampuan dan kesopanan. Komunikasi yang baik merupakan salah satu kunci dalam berinteraksi dengan pelanggan. Komunikasi yang dilakukan oleh seluruh divisi termasuk divisi tiket domestik yaitu memberikan informasi yang jelas kepada pelanggan baik itu bertatap muka langsung maupun melalui telepon atau Yahoo Messenger mengenai tiket maskapai penerbangan dan mendengarkan keluhan dari pelanggan dengan baik. 
Kredibilitas merupakan yang tentunya sangat diharapkan pelanggan dalam menumbuhkan kepercayaan pelanggan. Kredibilitas karyawan dalam memberikan pelayanannya yaitu memesankan dan memberikan tiket maskapai penerbangan yang memang berkualitas secara jujur dan dapat dipercaya sesuai kebutuhan pelanggan. Keamanan dalam mendapatkan produk yang diinginkan pelanggan dan keamanan dalam proses transaksi merupakan keharusan bagi karyawan unutk memberikan rasa aman kepada pelanggan. Keamanan yang diberikan yaitu kepastian kepada pelanggan bahwa pelanggan akan mendapatkan tiket maskapai penerbangan tersebut sesuai kebutuhan pelanggan dan privasi pelanggan yang melakukan transaksi sangat dijaga.

Kemampuan karyawan sangat diutamakan dalam memahami kebutuhan wisatawan. Kemampuan karyawan sangat dituntut dalam memberikan produk sesuai permintaan pelanggan dengan keahlian yang dimiliki karyawan pada divisi ticketing domestik sehingga memenuhi kebutuhan dan keinginan pelanggan. Kesopanan merupakan pelayanan yang selalu diberikan kepada wisatawan. Karyawan harus memberikan keramahan dalam melayani pelanggan, bersikap yang baik kepada pelanggan.

Implementasi yang dilakukan oleh PT. Interlink Tours andTtravel Bandung sejalan dengan pendapat Parasuraman (dalam Ririn Tri Ratnasari \& Mastuti H. Aksa, 2011:107) bahwa untuk mengukur keefektifan assurance dapat menggunakan dimensi komunikasi (communication), kredibilitas (credibility), keamanan (security), kompetensi (competence), dan sopan santun (courtesy). Dalam mengimplementasikan assurance, diperlukan karyawan yang berorientasi kepada pelanggan karena tanggung jawab dalam memberikan pelayanan menjadi perhatian semua personil produksi karena perusahaan ingin membangun loyalitas antara karyawan perusahaan dengan pelanggan.

Berdasarkan latar belakang diatas maka perlu diadakan suatu penelitian tentang "PENGARUH ASSURANCE TERHADAP LOYALITAS PELANGGAN CORPORATE TIKET MASKAPAI PENERBANGAN DOMESTIK PT. INTERLINK TOURS AND TRAVEL BANDUNG"

\subsection{Rumusan Masalah}

Berdasarkan latar belakang permasalahan yang telah dijelaskan di atas, maka dapat dirumuskan permasalahan pokok dalam penelitian ini adalah:

1. Bagaimana gambaran assurance yang terdiri dari communication, credibility, security, competence, dan courtesy di PT. Interlink Tours and Travel Bandung.

2. Bagaimana gambaran loyalitas pelanggan corporate tiket maskapai penerbangan domestik PT. Interlink Tours and Travel Bandung.

3. Bagaimana pengaruh assurance yang terdiri dari communication, credibility, security, competence, dan courtesy terhadap loyalitas pelanggan corporate tiket maskapai penerbangan domestik PT. Interlink Tours and Travel Bandung baik secara simultan maupun parsial.

\subsection{Tujuan Penelitian}

1. Untuk memperoleh gambaran mengenai assurance yang terdiri dari communication, credibility, security, competence, dan courtesy di PT. Interlink Tours and Travel Bandung.

2. Untuk memperoleh gambaran mengenai loyalitas pelanggan corporate tiket maskapai penerbangan domestik PT. Interlink Tours and Travel Bandung.

3. Untuk memperoleh temuan mengenai pengaruh assurance yang terdiri dari communication, credibility, security, competence, dan courtesy terhadap loyalitas pelanggan tiket corporate maskapai penerbangan domestik PT. Interlink Tours and Travel Bandung.

\subsection{Kegunaan Penelitian}

\subsubsection{Teoritis}

Hasil penelitian diharapkan dapat memperluas kajian ilmu manajemen pemasaran pariwisata khususnya assurance dan loyalitas, serta dapat berguna bagi peneliti dalam mengembangkan ilmu pariwisata.

\subsubsection{Praktis}

1. Secara praktis hasil penelitian ini diharapkan dapat digunakan terus oleh PT. Interlink Tours and Travel Bandung dalam menentukan langkah dan kebijakan perusahaan khususnya dalam penentuan 
strategi pemasaran jasa yang berorientasi

pada loyalitas pelanggan.

2. Secara praktis hasil penelitian ini diharapkan dapat dijadikan inspirasi dan motivasi bagi Dinas Kebudayaan dan Pariwisata khususnya di wilayah provinsi Jawa Barat, Kota Bandung, maupun Kabupaten Bandung dalam menentukan strategi pemasaran pariwisata.

\section{KERANGKA PEMIKIRAN DAN HIPOTESIS}

\subsection{Kerangka Pemikiran}

Konsep pemasaran saat ini fokus pada pelanggan yang akan bersedia membeli produk yang mampu memenuhi kebutuhan dan keinginannya serta memberikan kepuasan sehingga menciptakan loyalitas. Sektor jasa telah mengalami peningkatan yang pesat dibanding dekade sebelumnya. Dinamika yang terjadi pada sektor jasa terlihat dari perkembangan berbagai industri jasa salah satunya pariwisata. Pariwisata merupakan segala kegiatan yang dilakukan selama perjalanan wisata dari mulai wisatawan itu berangkat, tinggal di tempat wisata hingga wisatawan itu kembali. Konsumsi jasa pariwisata seperti usaha perjalanan wisata, penginapan dan restoran memiliki pengaruh besar atas perkembangan perekonomian. Salah satu usaha perjalanan yang berkembang pesat adalah usaha perjalanan wisata. Pelayanan sangat penting bagi perusahaan jasa seperti usaha perjalanan wisata dijadikan perhatian khusus bagi perusahan sebagai upaya peningkatan keunggulan kompetitif bisinisnya. Pelanggan adalah kunci untuk meraih keuntungan. Hal itulah yang menjadi fokus dari perusahaan usaha perjalanan wisata PT. Interlink Tours and Travel Bandung. Pada tahun 2011, loyalitas pelanggan PT. Interlink Tours and Travel Bandung mengalami penurunan baik dari jumlah pelanggan maupun dari rata-rata frekuensi pelanggan menggunakan jasa perusahaan dalam penyediaan tiket maskapai penerbangan domestik.

Setiap karyawan usaha perjalanan wisata khususnya manajer perusahaan harus mampu membaca kondisi dan keadaan pasar dalam menentukan strategi pemasaran. Strategi yang dilakukan perusahaan PT. Interlink Tours and Travel Bandung adalah untuk memperoleh keuntungan yang besar melalui pembelian berulang-ulang tiket maskapai penerbangan domestik, maka dari itu dibutuhkan kepuasan dari pelanggan dan komunikasi yang tetap terjalin dengan pelanggan. Salah satu alat dari strategi yang biasa digunakan adalah bauran pemasaran. Bauran pemasaran berdasarkan definisi para ahli adalah strategi yang terdiri dari seperangkat alat pemasaran yang digunakan untuk menyampaikan produk perusahaan kepada pelanggan dengan tepat.

Menjadi organisasi yang fokus pada pelanggan adalah pilihan strategis bagi industri dan dunia usaha khusunya jasa agar mampu bertahan di tengah persaingan bisnis yang cukup ketat. Salah satu cara adalah dengan menciptakan kepuasan pelanggan dan loyalitas pelanggan melalui peningkatan kualitas jasa (Service Quality). Berdasarkan definisidefinisi dari para ahli, kualitas jasa merupakan seberapa jauh harapan dan keinginan atas pelayanan yang didapat melampaui persepsi pelanggan atau tidak.

Terdapat lima dimensi dalam kualitas jasa yaitu tangible (penampilan elemenelemen fisik), reliability (kehandalan dan keakuratan kinerja), responsiveness (ketepatan dan kegunaaan), assurance (kredibilitas, keamanan, kompetensi, dan kesopanan), dan empathy (akses yang mudah, komunikasi yang baik, dan memahami pelanggan). Assurance merupakan salah satu dimensi penggerak kualitas jasa yang dapat digunakan untuk memberikan pelayanan yang prima kepada pelanggan. Berdasarkan definisi dari para ahli, Assurance merupakan pengetahuan dan kesopanan yang dimiliki perusahaan dan karyawannya untuk menciptakan kepercayaan dan keyakinan kepada pelanggan.

Dalam assurance terdapat lima dimensi yang dapat digunakan untuk mengukur efektifitas dari pelayanan kepada pelanggan, 
yaitu communication, credibility, security, competence, dan courtesy. Penjelasan kelima dimensi assurance yaitu Communication (komunikasi) adalah memberikan informasi yang jelas kepada para pelanggan dalam bahasa yang dapat dipahami, serta bersedia mendengarkan saran dan keluhan pelanggan. Credibility (kredibilitas) yakni sifat jujur dan dapat dipercaya dalam memberikan pelayanan. Security (keamanan) yakni bebas dari bahaya, risiko, atau keragu-raguan atas pelayanan yang diberikan kepada pelanggan. Competence (kompetensi) merupakan penguasaan keterampilan dan pengetahuan yang dimiliki karyawan agar dapat memberikan jasa yang dibutuhkan pelanggan. Courtesy (sopan santun) yaitu sikap sopan santun, respek, perhatian,keramahan dan kerapihan dalam berpakaian para staf lini depan. PT. Interlink Tours and Travel Bandung sebagai industri yang bergerak di bidang jasa pariwisata menerapkan kelima dimensi dari Assurance tersebut untuk meningkatkan loyalitas pelanggan. Dimensi-dimensi yang dilakukan dalam berinteraksi dengan para pelanggan diantaranya, pelaksanaan dimensi communication yang dilakukan oleh seluruh divisi termasuk divisi tiket domestik yaitu memberikan informasi yang jelas kepada pelanggan baik itu bertatap muka langsung maupun melalui telepon atau Yahoo Messenger mengenai tiket maskapai penerbangan dan mendengarkan keluhan dari pelanggan dengan baik baik secara langsung maupun melalui telepon dan Yahoo Messenger.

Pelaksanaan dimensi credibility, yaitu memesankan dan memberikan tiket maskapai penerbangan yang memang berkualitas secara jujur dan dapat dipercaya sesuai kebutuhan pelanggan. Pelaksanaan dimensi security yaitu memberikan kepastian kepada pelanggan bahwa pelanggan akan mendapatkan tiket maskapai penerbangan tersebut sesuai kebutuhan pelanggan. Pelaksanaan dimensi competence, karyawan memberikan produk sesuai permintaan pelanggan dengan keahlian yang dimiliki karyawan pada divisi tiketing domestik sehingga memenuhi kebutuhan dan keinginan pelanggan. Pelaksanaan dimensi courtesy, karyawan harus memberikan keramahan dalam melayani pelanggan, bersikap yang baik kepada pelanggan.
PT. Interlink Tours and Travel Bandung menekankan kebijakan-kebijakan tersebut yang termasuk ke dalam dimensi assurance dengan tujuan untuk meningkatkan keuntungan yang besar yang bersumber pada pelanggan yang membeli tiket maskapai penerbangan domestik secara berulang-ulang sehingga menciptakan persepsi pelanggan yang merasa membutuhkan PT. Interlink Tours and Travel Bandung dalam menyediakan tiket maskapai penerbangan domestik. Hal yang menjadi fokus dari PT. Interlink Tours and Travel Bandung adalah mempertahankan dan meningkatkan loyalitas pelanggan. Loyalitas pelanggan menurut para ahli merupakan perilaku dan sikap pelanggan yang menghasilkan respon positif dan negatif dalam pembelian terhadap barang atau jasa suatu perusahaan yang dipilih dalam jangka panjang sehingga mempertahankan hubungan antara perusahaan dengan pelanggan.

Pelanggan yang loyal merupakan aset penting bagi perusahaan. Terdapat dua dimensi untuk mengukur loyalitas yang didasarkan pada behaviour (perilaku) seperti proporsi membeli, waktu yang digunakan untuk membeli produk atau jasa, dan pembelian dalam jangka waktu mingguan. Didasarkan pada attitude (sikap) seperti kepercayaan dan komitmen. Membina hubungan dengan pelanggan dapat dilakukan dengan memberikan pelayanan yang sangat baik dan konsisten. Hal tersebut akan menciptakan kepuasan pelanggan yang menunjukkan loyalitas. Hal inilah yang mendorong PT. Interlink Tours and Travel Bandung mengembangkan teknik untuk meningkatkan kepuasan pelanggan demi mencapai pelanggan yang loyal. Berdasarkan penjelasan teori di atas, secara teoritis penjelasan assurance yang terdiri dari communication, credibility, security, competence dan courtesy mempunyai hubungan yang positif terhadap loyalitas pelanggan. Keterkaitan antara dua konsep di atas merupakan kerangka berpikir yang dijadikan landasan dalam penelitian sebagaimana terlihat dalam gambar di bawah ini: 


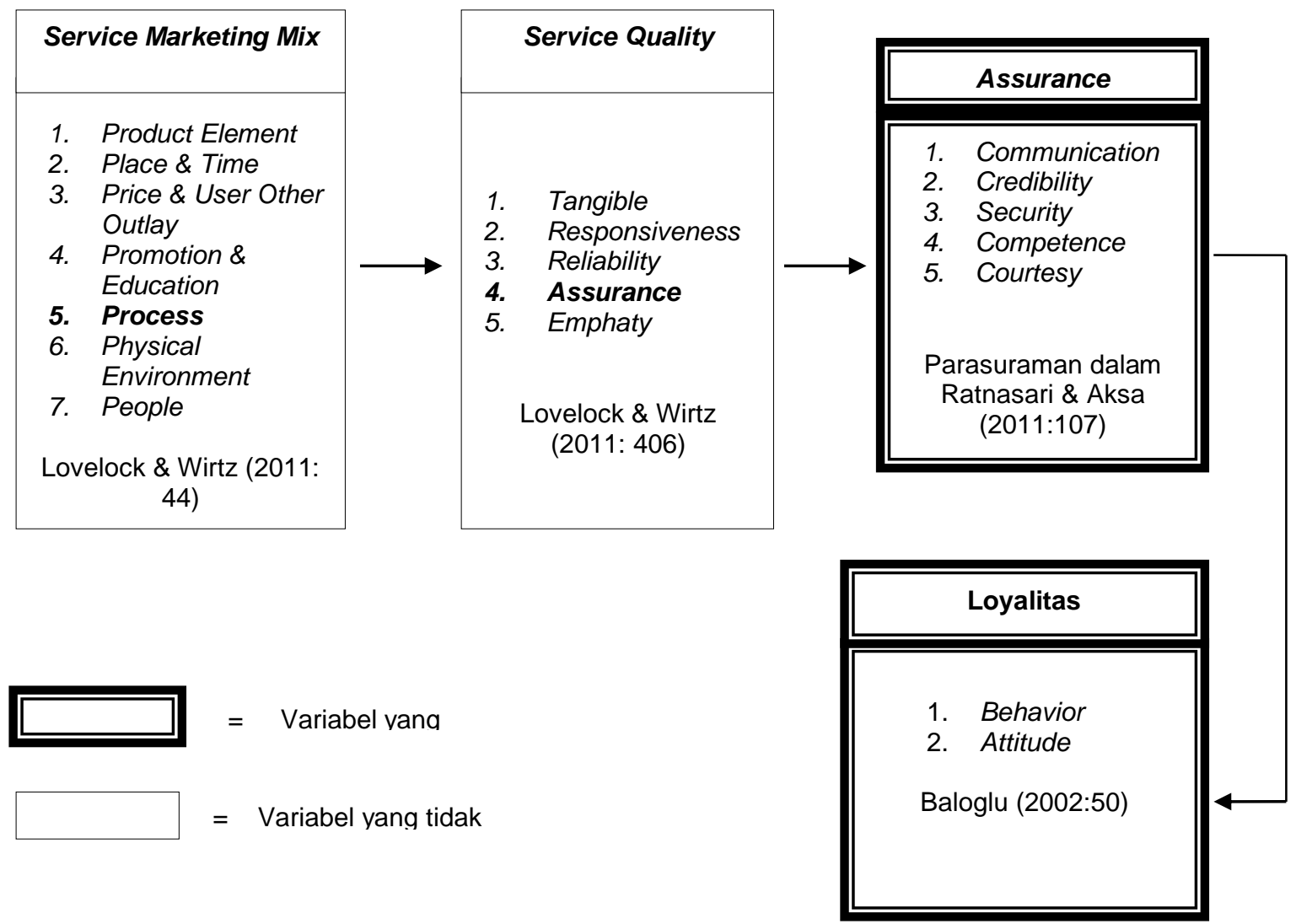

GAMBAR 2.4

\section{KERANGKA PEMIKIRAN PENGARUH ASSURANCE TERHADAP LOYALITAS PELANGGAN CORPORATE TIKET MASKAPAI PENERBANGAN DOMESTIK PT. INTERLINK TOURS AND TRAVEL BANDUNG}

\subsection{Hipotesis Penelitian}

Sugiyono (2011: 64) mengutarakan bahwa hipotesis merupakan jawaban sementara terhadap rumusan masalah penelitian, dimana rumusan masalah penelitian telah dinyatakan dalam bentuk kalimat pertanyaan. Jadi, hipotesis juga dapat dinyatakan sebagai jawaban teoritis terhadap rumusan masalah penelitian, belum merupakan jawaban yang empirik.

Peneliti dalam menyusun hipotesis didukung oleh beberapa premis sebagai berikut:
1. Caruana et al., 2000; Caruana, 2002 (dalam International Journal of Marketing Studies Vol 2, 2010:62)

The practice of excellent service quality has been proven that customer satisfaction will significantly lead to customer loyalty

2. Zeithaml et al. (2009:114) Assurance is defined as employees' knowledge and courtesy and ability of the firm and its employees to inspire trust and confidence. Trust and confidence may be embodied in the person who link the customer to the company. In such 
service contexts the company seeks to build trust and loyalty between key contact people and individual customers.

3. Fandy Tjiptono (2011:584)

Assurance yang efektif bisa meningkatkan profitabilitas melalui peningkatan customer awareness, loyalitas pelanggan, komunikasi positif, reduksi biaya, dan terciptanya budaya layanan yang lebih kondusif.

Berdasarkan uraian premis beberapa ahli diatas, peneliti mengemukakan hipotesis sebagai berikut: Terdapat pengaruh yang positif dari Assurance yang meliputi communication, credibility, security, competence dan courtesy terhadap Loyalitas Pelanggan.

\section{OBJEK DAN METODE} PENELITIAN

\subsection{Objek Penelitian}

Objek Penelitian menurut Sugiyono (2011:39) adalah "suatu atribut atau sifat atau nilai dari orang, obyek atau kegiatan yang mempunyai variasi tertentu yang ditetapkan oleh peneliti untuk dipelajari dan kemudian ditarik kesimpulannya". Objek penelitian sebagai variabel bebas (independent variable) adalah assurance yang memiliki lima dimensi yaitu communication, credibility, security, competence, dan courtesy. Variable terikat (dependent variable) adalah loyalitas pelanggan yang terdiri dari behavior dan attitude.

\subsection{Metode Penelitian}

\subsubsection{Jenis dan Metode yang Digunakan}

Berdasarkan variabel-variabel yang diteliti maka jenis penelitian ini adalah penelitian deskriptif dan verifikatif. Menurut Freddy Rangkuti (2011:17), penelitian deskriptif adalah penelitian yang bertujuan menjelaskan karakteristik pasar. Penelitian deskriptif disini bertujuan untuk memperoleh gambaran mengenai karakteristik assurance dan loyalitas pelanggan corporate tiket maskapai penerbangan domestik di PT. Interlink Tour \& Travel Bandung.

Adapun penelitian verifikatif atau kausal yaitu penelitian yang bertujuan mencari hubungan antara sebab dan akibat (Freddy
Rangkuti. 2011:24). Pada penelitian verifikatif terdapat variabel yang menjadi penyebab atau variabel pengaruh ( variabel independen) dan variabel yang menjadi akibat atau variabel terpengaruh (variabel dependen). Dalam penelitian ini, penelitian verifikatif bertujuan untuk mengetahui pengaruh assurance (variabel independen) terhadap loyalitas pelanggan (variabel dependen) corporate tiket maskapai penerbangan domestik di PT. Interlink Tour \& Travel Bandung.

Berdasarkan variabel yang diteliti maka jenis penelitian ini merupakan penelitian deskriptif dan verifikatif, dilaksanakan melalui pengumpulan data di lapangan melalui pengajuan pertanyaan terstruktur kepada responden. Metode penelitian yang digunakan adalah metode explanatory survey. Menurut Istijanto (2009:56) metode survei adalah metode yang digunakan untuk mengumpulkan informasi dengan menanyai orang melalui daftar pertanyaan atau kuesioner yang terstruktur.

Dalam penelitian yang menggunakan metode ini, informasi dari populasi dikumpulkan langsung ditempat secara empirik dengan tujuan untuk mengetahui pendapat dari populasi terhadap objek yang sedang diteliti. Penelitian ini dilakukan pada satu saat tertentu yang dinamakan cross sectional (Freddy Rangkuti, 2011:20). Penelitian ini dilakukan dalam kurun waktu kurang dari satu tahun.

\subsubsection{Operasionalisasi Variabel}

Dalam penelitian ini variabel yang diteliti adalah assurance sebagai variabel $\mathrm{X}$ dan loyalitas pelanggan sebagai variabel $\mathrm{Y}$. Assurance terdiri dari communication, credibility, security, competence, dan courtesy Sedangkan loyalitas pelanggan terdiri dari behaviour dan attitude. Berikut ini tabel operasionalisasi variabel dari kedua variabel tersebut: 
TABEL 3.1

OPERASIONALISASI VARIABEL PENELITIAN

\begin{tabular}{|c|c|c|c|c|c|}
\hline $\begin{array}{c}\text { Variabel/Sub } \\
\text { Variabel }\end{array}$ & Konsep Variabel & Indikator & Ukuran & Skala & $\begin{array}{c}\text { No. Item } \\
\text { Pertanyaan }\end{array}$ \\
\hline Assurance $(\mathrm{X})$ & $\begin{array}{l}\text { pengetahuan } \\
\text { karyawan dan } \\
\text { kesopanan dan } \\
\text { kemampuan } \\
\text { perusahaan dan } \\
\text { karyawannya untuk } \\
\text { mengilhami } \\
\text { kepercayaan dan } \\
\text { keyakinan. } \\
\text { (Parasuraman } \\
\text { dalam Ririn Tri } \\
\text { Ratnasari, } \\
\text { 2011:109) }\end{array}$ & & & & \\
\hline \multirow[t]{4}{*}{$\begin{array}{c}\text { Communication } \\
\text { (X.1) }\end{array}$} & \multirow{4}{*}{$\begin{array}{l}\text { Memberikan } \\
\text { informasi kepada } \\
\text { para pelanggan } \\
\text { dalam bahasa yang } \\
\text { dapat pelanggan } \\
\text { pahami, serta } \\
\text { selalu } \\
\text { mendengarkan } \\
\text { saran dan keluhan } \\
\text { pelanggan (Fandy } \\
\text { Tjiptono, } \\
\text { 2011:349) }\end{array}$} & $\begin{array}{l}\text { Kejelasan } \\
\text { informasi }\end{array}$ & $\begin{array}{l}\text { Tingkat kejelasan } \\
\text { informasi yang } \\
\text { diberikan } \\
\text { karyawan }\end{array}$ & Ordinal & C.1.1 \\
\hline & & $\begin{array}{l}\text { Kecepatan } \\
\text { memberikan } \\
\text { informasi }\end{array}$ & $\begin{array}{l}\text { Tingkat kecepatan } \\
\text { karyawan } \\
\text { memberikan } \\
\text { informasi kepada } \\
\text { pelanggan melalui } \\
\text { telepon/YM/tatap } \\
\text { muka langsung }\end{array}$ & Ordinal & C.1.2 \\
\hline & & $\begin{array}{l}\text { Pemahaman } \\
\text { bahasa yang } \\
\text { digunakan }\end{array}$ & $\begin{array}{l}\text { Tingkat } \\
\text { pemahaman } \\
\text { pelanggan akan } \\
\text { bahasa yang } \\
\text { digunakan } \\
\text { karyawan } \\
\end{array}$ & Ordinal & $\begin{array}{l}\text { C.1.3 } \\
\end{array}$ \\
\hline & & $\begin{array}{l}\text { Kebersediaan } \\
\text { mendengarkan } \\
\text { saran atau } \\
\text { keluhan }\end{array}$ & $\begin{array}{l}\text { Tingkat } \\
\text { kebersediaan } \\
\text { karyawan } \\
\text { mendengarkan } \\
\text { saran atau keluhan } \\
\text { pelanggan }\end{array}$ & Ordinal & $\begin{array}{l}\text { C.1.4 } \\
\end{array}$ \\
\hline $\begin{array}{l}\text { Credibility } \\
\text { (X.2) }\end{array}$ & $\begin{array}{l}\text { Sifat jujur dan } \\
\text { dapat dipercaya } \\
\text { (Fandy Tjiptono, } \\
\text { 2011:348) }\end{array}$ & $\begin{array}{l}\text { Kejujuran } \\
\text { karyawan } \\
\text { dalam } \\
\text { memberikan } \\
\text { informasi } \\
\text { kepada } \\
\text { pelanggan }\end{array}$ & $\begin{array}{l}\text { Tingkat kejujuran } \\
\text { karyawan dalam } \\
\text { memberikan } \\
\text { informasi kepada } \\
\text { pelanggan }\end{array}$ & Ordinal & C.2.1 \\
\hline
\end{tabular}




\begin{tabular}{|c|c|c|c|c|c|}
\hline & & $\begin{array}{l}\text { Kepercayaan } \\
\text { pelanggan atas } \\
\text { informasi yang } \\
\text { didapat }\end{array}$ & $\begin{array}{l}\text { Tingkat } \\
\text { kepercayaan } \\
\text { pelanggan kepada } \\
\text { karyawan dalam } \\
\text { memberikan } \\
\text { informasi }\end{array}$ & Ordinal & C.2.2 \\
\hline & & $\begin{array}{l}\text { Ketepatan } \\
\text { dalam } \\
\text { menepati janji }\end{array}$ & $\begin{array}{l}\text { Tingkat ketepatan } \\
\text { dalam menepati } \\
\text { janji kepada } \\
\text { pelanggan dalam } \\
\text { proses pemesanan } \\
\text { tiket }\end{array}$ & Ordinal & C.2.3 \\
\hline \multirow[t]{3}{*}{$\begin{array}{l}\text { Security } \\
\text { (X.3) }\end{array}$} & \multirow[t]{3}{*}{$\begin{array}{l}\text { Bebas dari bahaya, } \\
\text { risiko, atau keragu- } \\
\text { raguan }(2011: 348)\end{array}$} & $\begin{array}{l}\text { keyakinan } \\
\text { pelanggan } \\
\text { mendapatkan } \\
\text { tiketnya sesuai } \\
\text { kebutuhan }\end{array}$ & $\begin{array}{l}\text { Tingkat keyakinan } \\
\text { pelanggan } \\
\text { mendapatkan } \\
\text { tiketnya sesuai } \\
\text { kebutuhan }\end{array}$ & Ordinal & C.3.1 \\
\hline & & $\begin{array}{l}\text { Keamanan } \\
\text { pelanggan } \\
\text { memperoleh } \\
\text { tiket }\end{array}$ & $\begin{array}{l}\text { Tingkat keamanan } \\
\text { memperoleh tiket } \\
\text { maskapai } \\
\text { penerbangan } \\
\text { domestik }\end{array}$ & Ordinal & C.3.2 \\
\hline & & $\begin{array}{l}\text { Keamanan } \\
\text { privasi } \\
\text { pelanggan }\end{array}$ & $\begin{array}{l}\text { Tingkat keamanan } \\
\text { privasi pelanggan } \\
\text { dalam proses } \\
\text { pemesanan tiket }\end{array}$ & Ordinal & C.3.3 \\
\hline \multirow[t]{3}{*}{$\begin{array}{c}\text { Competence } \\
\text { (X.4) }\end{array}$} & \multirow{3}{*}{$\begin{array}{l}\text { Penguasaan } \\
\text { keterampilan dan } \\
\text { pengetahuan yang } \\
\text { dibutuhkan agar } \\
\text { dapat memberikan } \\
\text { jasa yang } \\
\text { dibutuhkan } \\
\text { pelanggan (Fandy } \\
\text { Tjiptono, } \\
\text { 2011:348) }\end{array}$} & $\begin{array}{l}\text { Keterampilan } \\
\text { melayani } \\
\text { kebutuhan } \\
\text { pelanggan }\end{array}$ & $\begin{array}{l}\text { Tingkat } \\
\text { Keterampilan } \\
\text { karyawan dalam } \\
\text { melayani } \\
\text { kebutuhan } \\
\text { pelanggan }\end{array}$ & Ordinal & C.4.1 \\
\hline & & $\begin{array}{l}\text { Pengetahuan } \\
\text { karyawan } \\
\text { tentang } \\
\text { informasi tiket }\end{array}$ & $\begin{array}{l}\text { Tingkat } \\
\text { pengetahuan } \\
\text { karyawan tentang } \\
\text { informasi tiket }\end{array}$ & Ordinal & C.4.2 \\
\hline & & $\begin{array}{l}\text { Kemampuan } \\
\text { memberikan } \\
\text { informasi }\end{array}$ & $\begin{array}{l}\text { Tingkat } \\
\text { kemampuan } \\
\text { karyawan } \\
\text { memberikan } \\
\text { informasi kepada } \\
\text { pelanggan }\end{array}$ & Ordinal & C.4.3 \\
\hline & & $\begin{array}{l}\text { Kemampuan } \\
\text { memahami } \\
\text { kebutuhan } \\
\text { pelanggan }\end{array}$ & $\begin{array}{l}\text { Tingkat } \\
\text { kemampuan } \\
\text { karyawan } \\
\text { memahami } \\
\text { kebutuhan } \\
\text { pelanggan }\end{array}$ & Ordinal & C.4.4 \\
\hline & & $\begin{array}{l}\text { Kecepatan } \\
\text { melayani } \\
\text { pelanggan }\end{array}$ & $\begin{array}{l}\text { Tingkat kecepatan } \\
\text { melayani pelanggan } \\
\text { yang membutuhkan } \\
\text { tiket }\end{array}$ & Ordinal & C.4.5 \\
\hline
\end{tabular}




\begin{tabular}{|c|c|c|c|c|c|}
\hline & & $\begin{array}{l}\text { Ketepatan } \\
\text { memberikan } \\
\text { tiket sesuai } \\
\text { kebutuhan }\end{array}$ & $\begin{array}{l}\text { Tingkat ketepatan } \\
\text { karyawan dalam } \\
\text { memberikan tiket } \\
\text { yang sesuai } \\
\text { kebutuhan } \\
\text { pelanggan }\end{array}$ & Ordinal & C.4.6 \\
\hline & & $\begin{array}{l}\text { Kecepatan } \\
\text { menangani } \\
\text { masalah }\end{array}$ & $\begin{array}{l}\text { Tingkat kecepatan } \\
\text { karyawan dalam } \\
\text { menangani masalah } \\
\text { yang dialami } \\
\text { pelanggan }\end{array}$ & Ordinal & C.4.7 \\
\hline \multirow[t]{4}{*}{$\begin{array}{l}\text { Courtesy } \\
(\mathbf{X . 5})\end{array}$} & \multirow{4}{*}{$\begin{array}{l}\text { Sikap sopan santun, } \\
\text { respek, perhatian, } \\
\text { dan keramahanpara } \\
\text { staf lini depan } \\
\text { (Fandy Tjiptono, } \\
\text { 2011:348) }\end{array}$} & Kesopanan & $\begin{array}{l}\text { Tingkat Kesopanan } \\
\text { karyawan dalam } \\
\text { melayani pelanggan }\end{array}$ & Ordinal & C.5.1 \\
\hline & & Respek & $\begin{array}{l}\text { Tingkat respek } \\
\text { karyawan dalam } \\
\text { melayani pelanggan }\end{array}$ & Ordinal & C.5.2 \\
\hline & & Perhatian & $\begin{array}{l}\text { Tingkat perhatian } \\
\text { yang diberikan } \\
\text { karyawan terhadap } \\
\text { kebutuhan } \\
\text { pelanggan }\end{array}$ & Ordinal & C.5.3 \\
\hline & & Keramahan & $\begin{array}{l}\text { Tingkat keramahan } \\
\text { karyawan melayani } \\
\text { pelanggan }\end{array}$ & Ordinal & $\begin{array}{l}\text { C.5.4 } \\
\end{array}$ \\
\hline $\begin{array}{l}\text { Loyalitas } \\
\text { Pelanggan } \\
\text { (Y) }\end{array}$ & $\begin{array}{l}\text { Loyalitas pelanggan } \\
\text { adalah konsep } \\
\text { multidimensi yang } \\
\text { melibatkan unsur- } \\
\text { unsur perilaku } \\
\text { (pembelian ulang) } \\
\text { dan unsur-unsur } \\
\text { sikap (komitmen) } \\
\text { (Baloglu, 2002:49) } \\
\end{array}$ & & & & \\
\hline \multirow[t]{4}{*}{ Behavior } & \multirow[t]{4}{*}{$\begin{array}{l}\text { Mengukur frekuensi } \\
\text { pembelian dari } \\
\text { berlangganan ulang } \\
\text { (Baloglu, 2002: ) }\end{array}$} & \multirow[t]{2}{*}{ Purchase } & $\begin{array}{l}\text { Tingkat keseringan } \\
\text { pelanggan } \\
\text { menggunakan jasa } \\
\text { perusahaan pada } \\
\text { tahun ini }\end{array}$ & Ordinal & D.1.1 \\
\hline & & & $\begin{array}{l}\text { Tingkat lamanya } \\
\text { waktu yang } \\
\text { dihabiskan } \\
\text { pelanggan dalam } \\
\text { menggunakan jasa }\end{array}$ & Ordinal & D.1.2 \\
\hline & & \multirow[t]{2}{*}{ Word of mouth } & $\begin{array}{l}\text { Tingkat keseringan } \\
\text { pelanggan } \\
\text { mengatakan hal- } \\
\text { hal yang baik } \\
\text { tentang pelayanan }\end{array}$ & Ordinal & D.1.3 \\
\hline & & & Tingkat keseringan & Ordinal & D.1.4 \\
\hline
\end{tabular}




\begin{tabular}{|c|c|c|c|c|c|}
\hline & & & $\begin{array}{l}\text { merekomendasikan } \\
\text { dan mengajak } \\
\text { orang lain }\end{array}$ & & \\
\hline & & & $\begin{array}{l}\text { Tingkat minat } \\
\text { menceritakan } \\
\text { pengalaman } \\
\text { menggunakan jasa } \\
\text { perusahaan kepada } \\
\text { orang lain }\end{array}$ & Ordinal & D.1.5 \\
\hline & & \multirow[b]{2}{*}{ Cooperation } & $\begin{array}{l}\text { Tingkat minat } \\
\text { memberikan saran } \\
\text { yang positif kepada } \\
\text { perusahaan }\end{array}$ & Ordinal & D.1.6 \\
\hline & & & $\begin{array}{l}\text { Tingkat minat } \\
\text { mengadukan } \\
\text { pelayanan yang } \\
\text { buruk kepada pihak } \\
\text { manajemen }\end{array}$ & Ordinal & D.1.7 \\
\hline \multirow[t]{7}{*}{ Attitude } & \multirow[t]{7}{*}{$\begin{array}{l}\text { Mengukur } \\
\text { kepercayaan, } \\
\text { komitmen dan biaya } \\
\text { peralihan pelanggan } \\
\text { kepada perusahaan } \\
\text { (Baloglu, 2002 ) }\end{array}$} & \multirow[b]{2}{*}{ Trust } & $\begin{array}{l}\text { Tingkat keyakinan } \\
\text { pelanggan akan } \\
\text { pelayanan yang } \\
\text { konsisten dalam } \\
\text { setiap transaksi }\end{array}$ & Ordinal & D.2.1 \\
\hline & & & $\begin{array}{l}\text { Tingkat } \\
\text { kepercayaan kepada } \\
\text { karyawan dalam } \\
\text { memenuhi } \\
\text { permintaan } \\
\text { pelanggan }\end{array}$ & Ordinal & D.2.2 \\
\hline & & \multirow[t]{2}{*}{ Commitment } & $\begin{array}{l}\text { Tingkat minat } \\
\text { memiliki komitmen } \\
\text { untuk terus } \\
\text { berlangganan }\end{array}$ & Ordinal & D.2.3 \\
\hline & & & $\begin{array}{l}\text { Tingkat minat untuk } \\
\text { tidak menggunakan } \\
\text { jasa perusahaan lain }\end{array}$ & Ordinal & D.2.4 \\
\hline & & \multirow{3}{*}{ Switching cost } & $\begin{array}{l}\text { Tingkat besarnya } \\
\text { biaya yang } \\
\text { dikorbankan untuk } \\
\text { menggunakan jasa } \\
\text { perusahaan lain }\end{array}$ & Ordinal & D.2.5 \\
\hline & & & $\begin{array}{l}\text { Tingkat besarnya } \\
\text { tenaga yang } \\
\text { dikorbankan untuk } \\
\text { menggunakan jasa } \\
\text { perusahaan lain }\end{array}$ & Ordinal & D.2.6 \\
\hline & & & $\begin{array}{l}\text { Tingkat besarnya } \\
\text { waktu yang } \\
\text { dikorbankan untuk } \\
\text { menggunakan jasa } \\
\text { perusahaan lain }\end{array}$ & Ordinal & D.2.7 \\
\hline
\end{tabular}


Sumber: Hasil pengolahan Data, 2012

\subsubsection{Metode Penarikan Sampel}

Sampel adalah suatu bagian yang ditarik dari populasi (Istijanto, 2009:113). Bila populasi besar, dan penelitian tidak mungkin mempelajari semua yang ada pada populasi, misalnya karena keterbatasan jumlah sumber daya baik dana, tenaga dan waktu, maka peneliti dapat menggunakan sampel yang diambil dari populasi tersebut. Penarikan sampel cenderung relatif lebih akurat dan data relatif lebih cepat dikumpulkan. Sampel merupakan perwakilan dari populasi penelitian. Dengan adanya sampel, maka waktu, tenaga dan biaya yang dikeluarkan oleh peneliti menjadi lebih efisien.

Sampel pada penelitian ini menggunakan populasi dari pelanggan tiket maskapai penerbangan domestik yang merupakan perusahaan swasta dan instansi pemerintahan serta agen perjalanan karena pelanggan tersebutlah yang melakukan pembelian tiket secara berulang-ulang yang berjumlah 39 responden. Istilah lain sampel jenuh adalah sensus, dimana semua anggota populasi dijadikan sampel.

\subsubsection{Prosedur Pengumpulan Data}

Pengumpulan data yang dilakukan penulis menggunakan teknik sebagai berikut:

1. Wawancara

2. Kuesioner

3. Studi Literatur

4. Observasi

\subsection{Hasil Pengujian Validitas dan} Reliabilitas

\subsubsection{Hasil Pengujian Validitas}

Berdasarkan hasil pengolahan data dengan menggunakan software komputer SPSS 18 menunjukkan bahwa item-item pertanyaan dalam kuesioner valid karena $r_{\text {hitung }}$ lebih besar jika dibandingkan dengan $r_{\text {tabel }}$ yang bernilai 0,374 .

\subsubsection{Hasil Pengujian Reabilitas}

Hasil pengujian reliabilitas assurance yang terdiri dari communication, credibility, security, competence dan courtesy dengan loyalitas pelanggan. Pengujian tersebut menggunakan SPSS 18 dengan model product moment (Pearson) dapat dikatakan reliabel. Hal tersebut dikarenakan, nilai reliabiliatas untuk kedua variabel tersebut sebesar 0,804 dan 0,889 lebih besar dari nilai minimal yaitu 0.70 .

\subsection{Pengujian Hipotesis}

Teknik untuk menguji data yang digunakan dalam penelitian kuantitatif ini adalah metode analisis verifikatif. maka dilakukan analisis regresi berganda. Untuk bisa memprediksi melalui regresi, maka data setiap variabel harus tersedia. Berdasarkan data tersebut peneliti harus menemukan persamaan regresi berganda melalui perhitungan sebagai berikut:

$\mathrm{Y}=\mathrm{a}+\mathrm{b}_{1} \mathrm{X}_{1}+\mathrm{b}_{2} \mathrm{X}_{2}+\mathrm{b}_{3} \mathrm{X}_{3}+\mathrm{b}_{4} \mathrm{X}_{4}+\mathrm{b}_{5} \mathrm{X}_{5}$

Keterangan:

$\mathrm{Y}=$ variabel terikat (variabel

yang diduga)

$\mathrm{X}_{1}, \mathrm{X}_{2}, \mathrm{X}_{3}, \mathrm{X}_{4}, \mathrm{X}_{5}=$ variabel bebas I, II, III, IV dan $\mathrm{V}$

a $\quad=$ intersep atau konstanta

$\mathrm{b}_{1}, \mathrm{~b}_{2}, \mathrm{~b}_{3}, \mathrm{~b}_{4}, \mathrm{~b}_{5} \quad=$ koefisien regresi $($ slop $)$

Analisis regresi berganda akan dilakukan bila jumlah variabel independen minimal dua atau lebih. Menerjemahkan ke dalam beberapa sub hipotesis yang menyatakan pengaruh sub variabel independen yang paling dominan terhadap variabel dependen, lebih jelasnya dapat dilihat pada Gambar 3.1 berikut:

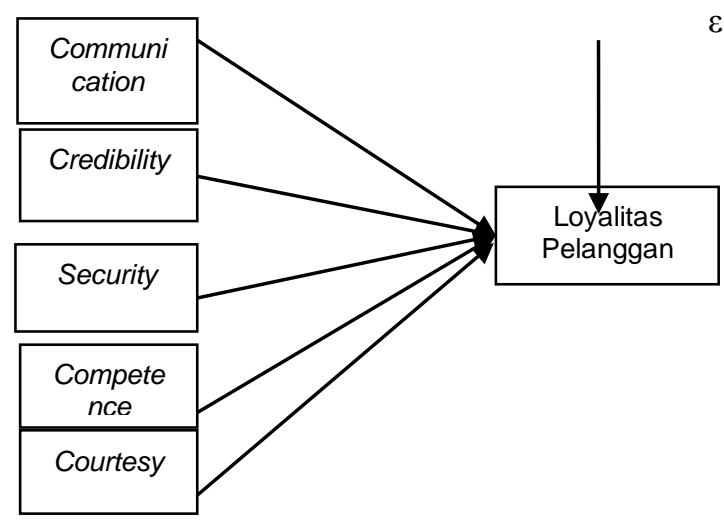

GAMBAR 3.1 REGRESI BERGANDA 
Dalam hal ini dilakukan pengujian hipotesis secara silmutan dan parsial.

\section{Pengujian Hipotesis Secara Simultan}

Kriteria pengujian untuk hipotesis yang diajukan secara simultan adalah:

Dengan level of significance $(\alpha)=0.05$

Degree of freedom $=(\mathrm{k}-1)(\mathrm{n}-\mathrm{k})$

$\mathrm{H}_{0}$ ditolak, jika $\mathrm{F}_{\text {hitung }}>\mathrm{F}_{\text {tabel, }}$, atau Sig. $\geq \alpha$

$\mathrm{H}_{0}$ diterima, jika $\mathrm{F}_{\text {hitung }}<\mathrm{F}_{\text {tabel }}$, atau Sig. $\leq \alpha$

Jika statistik menghasilkan satu harga yang ada dalam daerah penolakan, maka $\mathrm{H}_{0}$ ditolak. Hipotesis yang akan diuji dalam rangka pengambilan keputusan penerimaan dan atau penolakan hipotesis dapat ditulis sebagai berikut:

$\mathrm{H}_{0}=0$, Tidak terdapat pengaruh yang positif dari assurance terhadap loyalitas pelanggan PT. Interlink Tours and Travel Bandung.

$\mathrm{H}_{\mathrm{a}} \neq 0$, terdapat pengaruh yang positif dari assurance terhadap loyalitas pelanggan PT. Interlink Tours and Travel Bandung.

\section{Pengujian Hipotesis Secara Parsial}

Kriteria pengujian untuk hipotesis yang diajukan secara parsial adalah:

Dengan level of significance $(\alpha)=0.05$

Degree of freedom $=(\mathrm{n}-\mathrm{k})$

$\mathrm{H}_{0}$ ditolak, jika $\mathrm{t}$ hitung $>\mathrm{t}$ tabel, atau Sig. $\geq \alpha$ Ha diterima, jika t hitung $<\mathrm{t}$ tabel, atau Sig. $\leq$ $\alpha$

Hipotesis yang akan diuji dalam rangka pengambilan keputusan penerimaan atau penolakan hipotesis dapat ditulis sebagai berikut:

Jika thitung $>\mathrm{t}_{\text {tabel }}$ maka $\mathrm{H}_{0}$ ditolak dan $\mathrm{H}_{\mathrm{a}}$ diterima:

$\mathrm{H}_{0}=0$, Tidak terdapat pengaruh yang positif dari communication terhadap

\section{HASIL PENELITIAN DAN} PEMBAHASAN

4.1 Gambaran program Assurance di Interlink

Rekapitulasi mengenai hasil penilaian pelanggan terhadap pelaksanaan assurance dalam upaya untuk meningkatkan loyalitas loyalitas pelanggan PT. Interlink Tours and Travel Bandung.

$\mathrm{H}_{\mathrm{a}} \neq 0$, terdapat pengaruh yang positif dari communication terhadap loyalitas pelanggan PT. Interlink Tours and Travel Bandung.

Jika $t_{\text {hitung }}>t_{\text {tabel }}$ maka $\mathrm{H}_{0}$ ditolak dan $\mathrm{H}_{\mathrm{a}}$ diterima:

$\mathrm{H}_{0}=0$, Tidak terdapat pengaruh yang positif dari credibility terhadap loyalitas pelanggan PT. Interlink Tours and Travel Bandung.

$\mathrm{H}_{\mathrm{a}} \neq 0$, terdapat pengaruh yang positif dari credibility terhadap loyalitas pelanggan PT. Interlink Tours and Travel Bandung.

Jika $\mathrm{t}_{\text {hitung }}>\mathrm{t}_{\text {tabel }}$ maka $\mathrm{H}_{0}$ ditolak dan $\mathrm{H}_{\mathrm{a}}$ diterima:

$\mathrm{H}_{0}=0$, Tidak terdapat pengaruh yang positif dari security terhadap loyalitas pelanggan PT. Interlink Tours and Travel Bandung.

$\mathrm{H}_{\mathrm{a}} \neq 0$, terdapat pengaruh yang positif dari security terhadap loyalitas pelanggan PT. Interlink Tours and Travel Bandung.

Jika $t_{\text {hitung }}>t_{\text {tabel }}$ maka $\mathrm{H}_{0}$ ditolak dan $\mathrm{H}_{\mathrm{a}}$ diterima:

$\mathrm{H}_{0}=0$, Tidak terdapat pengaruh yang positif dari competence terhadap loyalitas pelanggan PT. Interlink Tours and Travel Bandung.

$\mathrm{H}_{\mathrm{a}} \neq 0$, terdapat pengaruh yang positif dari competence terhadap loyalitas pelanggan PT. Interlink Tours and Travel Bandung.

Jika $\mathrm{t}_{\text {hitung }}>\mathrm{t}_{\text {tabel }}$ maka $\mathrm{H}_{0}$ ditolak dan $\mathrm{H}_{\mathrm{a}}$ diterima:

$\mathrm{H}_{0}=0$, Tidak terdapat pengaruh yang positif dari courtesy terhadap loyalitas pelanggan PT. Interlink Tours and Travel Bandung.

$\mathrm{H}_{\mathrm{a}} \neq 0$, terdapat pengaruh yang positif dari courtesy terhadap loyalitas pelanggan PT. Interlink Tours and Travel Bandung.

pelanggan Interlink Tours and Travel tersaji pada Tabel 4.1 berikut. 
TABEL 4.1

REKAPITULASI PROGRAM ASSURANCE DI INTERLINK TOURS AND TRAVEL

\begin{tabular}{|c|c|c|c|c|}
\hline NO & Sub Variabel & $\begin{array}{c}\text { Total } \\
\text { Skor }\end{array}$ & $\begin{array}{c}\text { Skor } \\
\text { Rata- } \\
\text { Rata }\end{array}$ & $\mathbf{\%}$ \\
\hline 1 & Communication & 604 & 151 & 19,1 \\
\hline 2 & Credibility & 466 & 155 & 19,6 \\
\hline 3 & Security & 494 & 165 & 21,0 \\
\hline 4 & Competence & 1104 & 158 & 20,0 \\
\hline 5 & Courtesy & 641 & 160 & 20,3 \\
\hline & TOTAL & $\mathbf{3 3 0 9}$ & $\mathbf{7 8 9}$ & $\mathbf{1 0 0}$ \\
\hline
\end{tabular}

Tabel 4.1 menunjukkan bahwa dimensi assurance yang mendapatkan penilaian skor paling besar yaitu pada security sebesar $21,0 \%$ dan yang mendapatkan penilaian skor paling kecil yaitu pada communication sebesar $19,1 \%$.

\subsection{Gambaran Loyalitas Pelanggan} Corporate Interlink Tours and Travel

Berdasarkan hasil pengolahan data dari kuesioner yang telah disebarkan kepada 39 responden yang menggunakan tiket maskapai penerbangan domestik di Interlink Tours and Travel Bandung diperoleh rekapitulasi loyalitas pelanggan sebagai berikut:

TABEL 4.2

\section{REKAPITULASI LOYALITAS PELANGGAN INTERLINK TOURS AND TRAVEL}

\begin{tabular}{|c|c|c|c|c|}
\hline NO & Sub Variabel & $\begin{array}{c}\text { Total } \\
\text { Skor }\end{array}$ & $\begin{array}{c}\text { Skor } \\
\text { Rata- } \\
\text { Rata }\end{array}$ & $\mathbf{\%}$ \\
\hline 1 & Behavior & 1028 & 146 & 49,8 \\
\hline 2 & Attitude & 1031 & 147 & 50,2 \\
\hline & TOTAL & $\mathbf{2 0 5 9}$ & $\mathbf{2 9 3}$ & $\mathbf{1 0 0}$ \\
\hline
\end{tabular}

Sumber: Hasil Pengolahan Data, 2012

Hasil rekapitulasi loyalitas pelanggan Interlink Tours and Travel menunjukkan dimensi attitude lebih besar yaitu 50,2\% . Sedangkan, dimensi behavior sebesar $49,8 \%$..

\subsection{Pengaruh Assurance terhadap Loyalitas Pelanggan Corporate Tiket Maskapai Penerbangan Domestik di Interlink Tours and Travel Bandung}

\section{Hasil Uji Asumsi Normalitas}

Pada analisis regresi data yang dimiliki harus berdistribusi normal. Uji normalitas bertujuan untuk mengetahui residual yang diteliti berdistribusi normal atau tidak. Nilai residual yang berdistribusi normal berupa kurva berbentuk lonceng (bell-shaped curve) yang kedua sisinya melebar sampai tak terhingga. Menurut Suliyanto (2005:63) cara mendeteksinya dengan menggunakan histogram regression residual yang sudah distandarkan dan kolmogorov-smirnov. Berikut histogram pada gambar 4.1

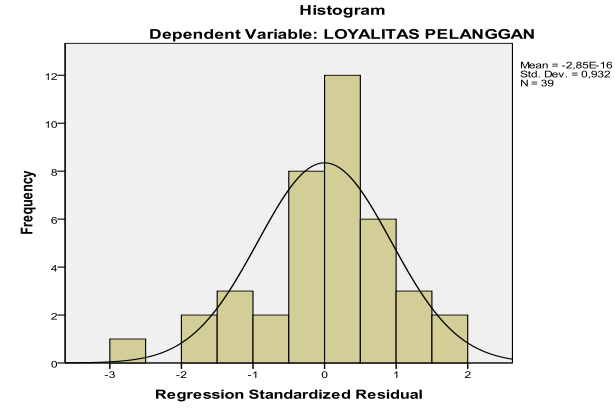

GAMBAR 4.1

HISTOGRAM DEPENDENT VARIABLE

Sumber: Pengolahan Data, 2012

Berdasarkan Gambar 4.1 diatas dapat dikatakan bahwa model berdistribusi normal karena kurva membetuk lonceng. Kemudian hasil analisis kolmogorov-smirnov disajikan dalan tabel 4.2 berikut.

TABEL 4.2

ONE SAMPLE KOLMOGOROV-SMIRNOV TEST

\begin{tabular}{|l|l|r|}
\hline \multicolumn{2}{|c|}{} & $\begin{array}{c}\text { Standardized } \\
\text { Residual }\end{array}$ \\
\hline $\mathrm{N}$ & 39 \\
\hline $\begin{array}{l}\text { Normal } \\
\text { Parametersa,b }\end{array}$ & Mean &, 0000000 \\
\cline { 2 - 3 } & $\begin{array}{l}\text { Std. } \\
\text { Deviation }\end{array}$ &, 93189112 \\
\hline $\begin{array}{l}\text { Most } \\
\text { Extreme } \\
\text { Differences }\end{array}$ & Absolute &, 104 \\
\cline { 2 - 3 } & Positive &, 065 \\
\cline { 2 - 3 } & Negative &,- 104 \\
\hline Kolmogorov-Smirnov Z &, 649 \\
\hline Asymp. Sig. (2-tailed) &, 794 \\
\hline \multicolumn{2}{|l|}{ Sumber: Pengolahan Data, 2012 }
\end{tabular}

\subsubsection{Hasil Uji Asumsi Variabel}


Berdasarkan tabel diatas, kurva nilai residual terstandardisasi dikatakan menyebar dengan normal apabila nilai asymp. sig (2tailed $)>\alpha$. Karena nilai asymp. sig $>0,05$ (alpha), maka nilai residual terstandardisasi dikatakan menyebar secara normal. Selain itu untuk mengetahui normalitas residual yang diteliti, data dapat diuji dengan menggunakan normal probability plot. Gambar 4.12 berikut ini menggambarkan normal probability plot yang digunakan untuk mendeteksi apakah data yang digunakan berdistribusi normal atau tidak.

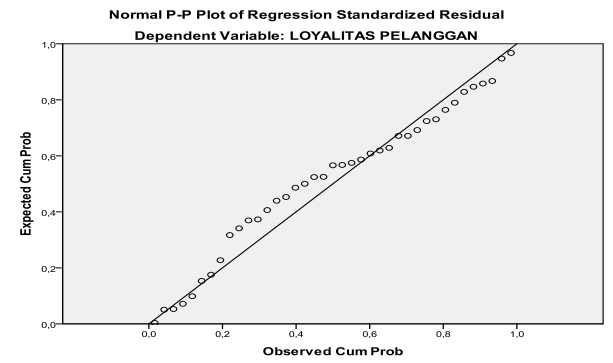

Sumber: Pengolahan Data, 2012

GAMBAR 4.3

NORMAL PROBABILITY PLOT

Nilai residu berdistribusi normal apabila sebaran datanya terletak disekitar garis diagonal dan mengikuti arah diagonal yaitu dari kiri bawah ke kanan atas. Berdasarkan gambar 4.12 data yang digunakan pada penelitian ini layak digunakan untuk model regresi karena berdistribusi normal.

\section{Hasil Uji Multikolinearitas}

Uji asumsi multikolinearitas bertujuan untuk mengetahui adanya hubungan yang mendekati sempurna antarvariabel bebas. Salah satu cara untuk mengetahui adanya multikolinearitas antarvariabel bebas dapat dilihat melalui nilai variance inflation factor (VIF) dari masing-masing variabel bebas terhadap variabel terikatnya. Menurut Algifari dalam Suliyanto (2005:63), jika nilai VIF tidak lebih dari 5, maka model tidak terdapat multikolinieritas. Jika dihasilkan nilai VIF yang lebih kecil dari 5, maka tidak ada hubungan antarvariabel bebas.
TABEL 4.3 UJI ASUMSI MULTIKOLINEARITAS

\begin{tabular}{|c|c|c|c|}
\hline \multirow{2}{*}{ Model } & \multicolumn{2}{c|}{ Collinearity Statistics } \\
\cline { 3 - 4 } & Tolerance & VIF \\
\hline \multirow{2}{*}{1} & (Constant) & & \\
\cline { 2 - 4 } & TOTALX1 &, 333 & 3,007 \\
\cline { 2 - 4 } & TOTALX2 &, 319 & 3,136 \\
\hline TOTALX3 &, 543 & 1,841 \\
\cline { 2 - 4 } & TOTALX4 &, 594 & 1,682 \\
\cline { 2 - 4 } & TOTALX5 &, 501 & 1,996 \\
\hline
\end{tabular}

Sumber: Pengolahan Data, 2012

Berdasarkan Tabel 4.11 diatas, diperoleh nilai VIF lebih kecil dari 5 sehingga pada penelitian ini tidak terdapat hubungan antarvariabel bebas.

\section{Hasil Uji Heteroskedastisitas}

Heteroskedastisitas merupakan pengujian untuk mengetahui adanya varian variabel dalam model yang tidak sama (Suliyanto, 2005:64). Untuk mendeteksi gejala heterodasititas, ada tau tidaknya pola yang terjadi pada nilai residu pada model. Suatu regresi dikatakan tidak terdeteksi heteroskedastisitas apabila penyebaran terhadap harga-harga prediksi tidak membentuk suatu pola tertentu (meningkat atau menurun). Berikut gambar 4.4 hasil uji asumsi heterodasititas

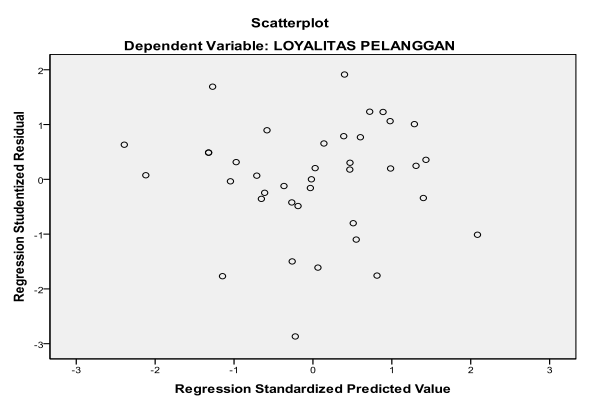

Sumber: Pengolahan Data, 2012

\section{GAMBAR 4.4 \\ HASIL UJI ASUMSI HETEROKEDASITITAS}

Berdasarkan Gambar 4.4 diatas, dapat dilihat bahwa sebaran tidak membentuk suatu pola. Hal ini menunjukkan bahwa pada penelitian ini data yang digunakan sudah layak untuk meneliti loyalitas pelanggan di PT. Interlink Tours and Travel 


\subsubsection{Koefisien Korelasi dan Determinasi}

Koefisien korelasi dan koefisien determinasi berfungsi untuk mengetahui seberapa kuat hubungan variabel assurance yang terdiri dari communication, credibility, security, competence dan courtesy dengan loyalitas pelanggan. Berikut hasil analisis koefisien korelasi dan koefisien determinasi tersaji pada Tabel 4.4

TABEL 4.4

HASIL ANALISIS ASSURANCE TERHADAP LOYALITAS PELANGGAN

\begin{tabular}{|c|c|c|c|c|c|}
\hline \multicolumn{2}{|c|}{ Model } & $\mathrm{R}$ & $\begin{array}{c}\mathrm{R} \\
\text { Square }\end{array}$ & $\begin{array}{c}\text { Adjusted } \\
\mathrm{R} \\
\text { Square }\end{array}$ & $\begin{array}{c}\text { Std. } \\
\text { Error of } \\
\text { the } \\
\text { Estimate }\end{array}$ \\
\hline & 1 &, 735 &, 540 &, 471 & 5,010870 \\
\hline
\end{tabular}

Sumber: Hasil Pengolahan Data Primer, 2012

Berdasarkan Tabel 4.4 diatas, dari hasil analisis diperoleh nilai koefisien korelasi $\mathrm{R}=0,735$. Merujuk pada interpretasi koefisien korelasi menurut Sugiyono (2011:184), nilai 0,735 masuk ke dalam interval koefisien 0,600,799 dengan tingkat hubungan kuat. Hal ini menunjukkan terdapat hubungan yang kuat dari assurance terhadap loyalitas pelanggan.

Berdasarkan hasil perhitungan diperoleh nilai koefisien determinasi $\mathrm{R}^{2}=0,540$. Hal ini menunjukkan bahwa besarnya nilai assurance dalam berkontribusi terhadap loyalitas pelanggan adalah sebesar 0,540. Sedangkan sisanya yaitu sebesar 0,460 dikontribusi oleh variabel lain yang tidak diteliti dalam penelitian ini.

\subsubsection{Pengujian Hipotesis dan Uji} Signifikansi Secara Simultan (Uji F)

Mengetahui seberapa besar kontribusi variabel bebas terhadap variabel terikat dapat dilakukan uji signifikansi secara simultan (uji F). Model penelitian dikatakan signifikan jika $\mathrm{F}$ hitung $>\mathrm{F}$ tabel atau nilai sig. $\mathrm{F} \leq \alpha$. Berikut hasil analisi uji $\mathrm{F}$ tersaji pada Tabel 4.5.

TABEL 4.5

OUTPUT ANOVA

\begin{tabular}{|c|c|c|c|c|c|c|}
\hline \multicolumn{2}{|c|}{ Model } & $\begin{array}{c}\text { Sum } \\
\text { of } \\
\text { Squar } \\
\text { es }\end{array}$ & $\begin{array}{c}\text { D } \\
\text { f }\end{array}$ & $\begin{array}{c}\text { Mean } \\
\text { Squar } \\
\text { e }\end{array}$ & F & $\begin{array}{c}\text { Si } \\
\text { g. }\end{array}$ \\
\hline 1 & $\begin{array}{c}\text { Regress } \\
\text { ion }\end{array}$ & $\begin{array}{c}974,0 \\
73\end{array}$ & 5 & 194,8 & 7,7 &, 00 \\
& & 15 & 59 & 0 \\
\hline
\end{tabular}

\begin{tabular}{|c|c|c|c|l|l|} 
Residua & 828,5 & 3 & 25,10 & & \\
1 & 91 & 3 & 9 & & \\
\hline Total & 1802, & 3 & & & \\
& 664 & 8 & & & \\
\hline
\end{tabular}

Sumber: Hasil Pengolahan Data Primer, 2012

Berdasarkan Tabel 4.13 diatas, hasil analisis menunjukkan $\mathrm{F}$ hitung $=7,759$ sedangkan $\mathrm{F}$ tabel pada derajat kebebasan 0,05 adalah sebesar 2,49 dan signifikansi $0,000 \leq$ 0,05. Dengan demikian $F_{\text {hitung }}=7,759>$ $F_{\text {tabel }}=2,49$ dengan signifikansi 0,000 maka analisis regresi dapat digunakan untuk memprediksi loyalitas pelanggan di PT. Interlink Tours and Travel sehingga $\mathrm{H}_{0}$ ditolak dan $\mathrm{H}_{\mathrm{a}}$ diterima. Pada penelitian ini disimpulkan bahwa assurance berpengaruh positif terhadap loyalitas pelanggan corporate PT. Interlink Tours and Travel.

\subsubsection{Pengujian Hipotesis dan Uji Signifikansi Secara Parsial (Uji t)}

Pengujian ini bertujuan untuk melihat pengaruh masing-masing variabel independen terhadap variabel dependen dan signifikan atau tidaknya. Selain itu, pengujian ini digunakan untuk mengetahui pengaruh variabel mana yang paling dominan dari keseluruhan variabel bebas yaitu communication, credibility, security, competence, dan courtesy. Regresi sebuah variabel mempunya pengaruh yang berarti terhadap perubahan nilai $\mathrm{Y}$ jika nilai $t_{\text {hitung }}>t_{\text {tabel }}$ atau sig.t $\leq \alpha$. Berikut penyajian hasil analisis dalam Tabel 4.6.

TABEL 4.6

HASIL ANALISIS KOEFISIEN REGRESI

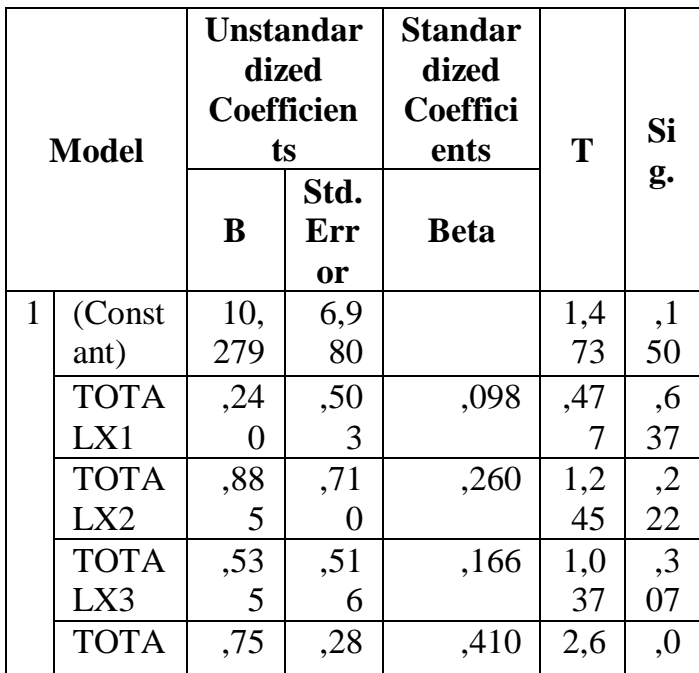




\begin{tabular}{|l|r|r|r|r|r|} 
LX4 & 5 & 2 & & 79 & 11 \\
\hline TOTA & - &, 43 &,- 060 & - &, 7 \\
LX5 &, 15 & 3 & &, 36 & 21 \\
& 6 & & & 0 & \\
\hline
\end{tabular}

Sumber: Hasil Pengolahan Data Primer, 2012

Berdasarkan Tabel 4.6 diatas, secara parsial menunjukkan bahwa tidak semua sub variabel bebas assurance memiliki signifikansi kurang dari 0,05 , artinya sub variabel-sub variabel tersebut tidak berpengaruh terhadap loyalitas pelanggan atau $\mathrm{H}_{0}$ diterima. Hasil analisis menunjukkan hanya satu variabel bebas yang memiliki signifikansi kurang dari 0,05 yaitu competence, artinya sub variabel ini berpengaruh terhadap loyalitas pelanggan atau $\mathrm{H}_{0}$ ditolak. Pada penelitian ini secara parsial disimpulkan bahwa

1. $\mathrm{t}_{\text {hitung }}=0,477<\mathrm{t}_{\text {tabel }}=2,042$ dan sig. $\mathrm{t}=0,637$ $\geq 0,05$, maka tidak terdapat pengaruh yang positif dari communication terhadap loyalitas pelanggan corporate PT. Interlink Tours and Travel Bandung.

2. $\mathrm{t}_{\text {hitung }}=1,245<\mathrm{t}_{\text {tabel }}=2,042$ dan sig.t $=0,222$ $\geq 0,05$, maka tidak terdapat pengaruh yang positif dari credibility terhadap loyalitas pelanggan corporate PT. Interlink Tours and Travel Bandung.

3. $\mathrm{t}_{\text {hitung }}=1,037<\mathrm{t}_{\text {tabel }}=2,042$ dan sig.t $=0,307$ $\geq 0,05$, bahwa tidak terdapat pengaruh yang positif dari security terhadap loyalitas pelanggan corporate PT. Interlink Tours and Travel Bandung.

4. $t_{\text {hitung }}=2,679>t_{\text {tabel }}=2,042$ dan sig.t $=0,011$ $\leq 0,05$, maka terdapat pengaruh yang positif dari competence terhadap loyalitas pelanggan corporate PT. Interlink Tours and Travel Bandung.

5. $\mathrm{t}_{\text {hitung }}=-0,360<\mathrm{t}_{\text {tabel }}=2,042$ dan sig.t $=$ 0,721 , maka tidak terdapat pengaruh yang positif dari courtesy terhadap loyalitas pelanggan corporate PT. Interlink Tours and Travel Bandung.

Berdasarkan kelima sub variabel tersebut hanya sub variabel competence yang memiliki pengaruh secara parsial terhadap loyalitas pelanggan. Sub variabel lainnya, yaitu communication, credibility, security, dan courtesy tidak memiliki pengaruh terhadap loyalitas pelanggan.

Competence ini merupakan variabel yang berpengaruh terhadap loyalitas pelanggan. Competence merupakan penguasaan keterampilan dan pengetahuan karyawan yang dibutuhkan pelanggan. Sejalan dengan Zeithaml (2009:114) "this dimension likely to be particularly important for service that customer perceive as high risk for service of which they feel uncertain about their ability to evaluate outcomes". Dimensi ini mungkin menjadi sangat penting untuk layanan yang pelanggan anggap sebagai risiko tinggi untuk layanan yang mereka rasa tidak pasti tentang kemampuan mereka untuk mengevaluasi hasil. Dari dimensi assurance ini pelayanan yang utama dibutuhkan oleh pelanggan adalah kompetensi dari karyawan. Sedangkan pengaruh paling kecil adalah courtesy Sebagai perusahaan jasa courtesy cukup penting dilaksanakan untuk memberikan rasa nyaman kepada pelanggan, namun pada penelitian ini courtesy tidak berpengaruh terhadap loyalitas pelanggan. Hal ini disebabkan karena pelanggan yang loyal sudah lebih mengenal karyawan perusahaan sehingga courtesy bukanlah pelayanan utama yang pelanggan perlukan.

\subsubsection{Model Persamaan Regresi Berganda Pengaruh Assurance terhadap Loyalitas Pelanggan Tiket Maskapai Penerbangan Domestik di Interlink Tours and Travel Bandung}

Persamaan regresi adalah suatu persamaan matematis yang mendefinisikan hubungan antara dua variabel. Persamaan regresi yang digunakan untuk membuat taksiran mengenai variabel dependen disebut persamaan regresi estimasi, yaitu suatu formula matematis yang menunjukkan hubungan keterkaitan antara satu atau beberapa variabel yang nilainya sudah diketahui dengan satu variabel yang nilainya belum diketahui. Bentuk persamaannya adalah

$$
\mathrm{Y}=\mathrm{a}+\mathrm{b}_{1} \mathrm{X}_{1}+\mathrm{b}_{2} \mathrm{X}_{2}+\mathrm{b}_{3} \mathrm{X}_{3}+\mathrm{b}_{4} \mathrm{X}_{4}+\mathrm{b}_{5} \mathrm{X}_{5}
$$

Berdasarkan hasil pengolahan data maka dihasilkan persamaan regresi sebagai berikut $\mathrm{Y}=10,297+0,240 \mathrm{X}_{1}+0,885 \mathrm{X}_{2}+0,535 \mathrm{X}_{3}+0,755$

$\mathrm{X}_{4}-0,156 \mathrm{X}_{5}$

Keterangan:

$\mathrm{Y}=$ loyalitas pelanggan

$\mathrm{X}_{1}=$ communication

$\mathrm{X}_{2}=$ credibility

$\mathrm{X}_{3}=$ security 
$\mathrm{X}_{4}=$ competence

$\mathrm{X}_{5}=$ courtesy

Hasil analisis menunjukkan nilai konstanta sebesar 10,297 artinya jika $\mathrm{X}_{1}, \mathrm{X}_{2}, \mathrm{X}_{3}, \mathrm{X}_{4}, \mathrm{X}_{5}$ diabaikan maka nilai loyalitas pelanggan adalah 10,297. Apabila nilai communication dinaikkan satu satuan maka nilai loyalitas pelanggan akan naik sebesar 0,240. Demikian dengan variabel credibility jika nilainya dinaikkan satu satuan maka nilai loyalitas pelanggan akan naik sebesar 0,885.kemudian variabel security, jika nilainya dinaikkan satu satuan maka nilai loyalitas pelanggan akan naik sebesar 0,535. Untuk variabel competence, jika nilainya dinaikkan satu satuan maka nilai loyalitas pelanggan akan naik sebesar 0,755. Sedangkan apabila nilai courtesy dinaikkan maka nilai loyalitas pelanggan akan berkurang sebesar 0,156.

\section{KESIMPULAN}

Berdasarkan kajian teori, hasil penelitian, dan pengujian regresi berganda yang dilaksanakan mengenai assurance terhadap loyalitas pelanggan PT. Interlink Tours and Travel, dapat disimpulkan sebagai berikut:

1. Gambaran mengenai assurance yang dilaksanakan di PT. Interlink Tours and Travel mendapat penilaian yang baik dari pelanggan. penilaian tertinggi diperoleh oleh security. Sedangkan penilaian terendah diperoleh oleh communication, seperti yang dijelaskan di bawah ini

a. Security merupakan jaminan yang diperlukan oleh pelanggan karena privasi pelanggan harus dijaga oleh pihak perusahaan agar pelanggan merasa aman bertransaksi dengan karyawan Interlink sehingga menimbulkan rasa aman pula untuk terus berlangganan pada perusahaan.

b. Communication mendapatkan nilai terendah. Hal ini disebabkan karena untuk mendapatkan penilaian yang baik dari pelanggan dibutuhkan karyawan yang bekerja secara cepat dan tepat untuk merespon permintaan pelanggan. Namun pada prakteknya kesalahan dapat terjadi terutama jika permintaan pelanggan datang pada saat high season dimana banyak tamu lain yang memesan tiket maskapai penerbangan khususnya domestik. Sehingga karyawan belum dapat memaksimalkan pelayanan khususnya communication kepada pelanggan, sedangkan pelanggan selalu menuntut pelayanan yang prima dari karyawan.

2. Gambaran mengenai loyalitas pelanggan corporate tiket maskapai penerbangan domestik PT. Interlink Tours and Travel berada pada posisi loyal. Kedua aspek dari loyalitas yaitu attitude dan behavior memperoleh hasil yang hampir seimbang. Hal ini menunjukkan frekuensi pembelian dan komitmen untuk terus berlangganan dari pelanggan cukup menjanjikan bagi eksistensi perusahaan Interlink Tours and Travel ke depannya.

3. Secara simultan terdapat pengaruh yang positif antara assurance terhadap loyalitas pelanggan. Namun secara parsial hanya sub variabel competence yang memberikan pengaruh terhadap loyalitas pelanggan, sedangkan empat subvariabel lainnya yaitu communication, credibility, security dan courtesy tidak memberikan pengaruh positif terhadap loyalitas pelanggan. Artinya, pemberian informasi kepada pelanggan, jujur dan dipercaya, pemberian rasa aman, serta sikap sopan santun yang dilakukan karyawan tiketing belum dirasa maksimal oleh pelanggan.

\section{DAFTAR PUSTAKA}

Ali, Moh. 1995. Penelitian Kependidikan Prosedur dan Strategi. Angkasa: Bandung.

Arikunto, Suharsimi. 2006. Prosedur Penelitian Suatu Pendekatan Praktik.

Damardjati, R.S. 2006. Istilah-Istilah Dunia Pariwisata. Cetakan Ketujuh. Pradnya Paramita: Jakarta.

Ebert, Ronald J. dan Griffin, Ricky W. 2007. Business Essentials. $6^{\text {th }}$ edition: Pearson Prentice Hall: USA.

Foster, Dennis L. 2000. First Class An Introduction To Travel \& Tourism. $2^{\text {th }}$ edition:Raja Grafindo Persada: Jakarta.

Gaffar, Vanessa. 2007. CRM dan MPR Hotel: Customer Relationship Management and Marketing Public Relations. Alfabeta: Bandung. 
Griffin, Jill. 2005. Customer Loyalty: Menumbuhkan \& Mempertahankan Kesetiaan Pelanggan. Erlangga: Jakarta.

Hasan, Iqbal. 2009. Analisis Data Penelitian dengan Statistik. Bumi Aksara: Jakarta.

Hurriyati, Ratih. 2010. Bauran Pemasaran dan Loyalitas Konsumen. Alfabeta. Bandung.

Istijanto. 2009. Aplikasi Praktis Riset Pemasaran: Cara Praktis Meneliti Konsumen dan Pesaing.Gramedia Pustaka Utama: Jakarta.

Lovelock, Christopher dan Wirtz, Jochen. 2011. Service Marketing: People, Technology, Strategy. $7^{\text {th }}$ edition: Pearson Education Inc: USA.

Lupiyoadi, Rambat dan Hamdani, A. 2008. Manajemen Pemasaran Jasa. Edisi 2. Salemba Empat: Jakarta.

Mill, Robert Christie. 2000. The Tourism International Business. Edisi Bahasa Indonesia. Grafindo: Jakarta.

Morrison. 2010. Marketing Hospitality and Travel Services. Delmar Publisher: Singapore.

Pendit, Nyoman S. 2002. Ilmu Pariwisata. Pradnya Paramita: Jakarta.

Rahmayanty, Nina. 2010. Manajemen Pelayanan Prima: Mencegah Pembelotan dan Membangun Customer Loyalty. Graha Ilmu: Yogyakarta.

Rangkuti, Freddy. 2011. Riset Pemasaran. Gramedia Pustaka Utama: Jakarta.

Ratnasari, Ririn Tri dan Aksa, Mastuti H. 2011. Manajemen Pemasaran Jasa. Ghalia Indonesia: Bogor.

Sugiyono. 2011. Metode Penelitian Kuantitatif Kualitatif dan $R \& D$. Alfabeta:Bandung.

Suliyanto. 2005. Analisis Data Dalam Aplikasi Pemasaran. Ghalia Indonesia.

Suwantoro, Gamal. 2004. Dasar-Dasar Pariwisata. Andi: Yogyakarta.

Tjiptono, Fandy. 2011. Pemasaran Jasa. Bayumedia Publishing: Jawa Timur.

Vellas, Francois dan Becherel, Lionel. 2008. Pemasaran Pariwisata International: Sebuah Pendekatan Strategis. Yayasan Obor Indonesia: Jakarta.

Warpani, Suwardjoko P dan Indira P. 2007. Pariwisata Dalam Tata Ruang Wilayah. Penerbit ITB: Bandung.
Yoeti, Oka A. 2006. Tours and Travel Management. PT. Pradnya Paramita: Jakarta.

(2006). Tours and Travel Marketing. PT. Pradnya Paramita: Jakarta.

Zeithaml, Valarie E., Bitner, Mary Jo. 2009. Bisnis, Services Marketing: Integrating Customer Focus Across the Firm. $5^{\text {th }}$ edition. The McGraw-Hill Companies Inc.: New York

\section{Jurnal dan Website}

Journal, Finn Adam et al (1994), Marketing Management and Competitive Strategy In The Ciltural Industry.

Journal, Jayaraman Munusamy, Shankar Chelliah dan Hor Wai Mun (2010), Service Quality Delivery and Its Impact on Customer Satisfaction in the Banking Sector in Malaysia.

Journal, Mohammad Muzahid Akbar dan Noorjahan Parvez (2009), Impact of Service Quality, Trust and Customer Satisfaction on Customer Loyalty.

Journal, Mei-Lien Li dan Robert D. Green (2009), A mediating influence on customer loyalty: The role of perceived value.

Journal, Sharon Schembri dan Jörgen Sandberg (2011), The experiential meaning of service quality.

Journal, Kazi Omar Siddiqi (2010), Interrelations between service quality attributes, customer satisfaction and customer loyalty in the retail banking sector in Bangladesh.

Journal, Sienny Thio (2001), Membangun Service Quality untuk Mencapai Kepuasan Konsumen di Industri Hospitality.

Journal, Any Noor (2006), Service Quality and Price Influence Customer Decision Making in Choosing to Fly With Low Cost Airlines.

Journal, Wanjohi Kibicho (2006), Service Quality in Malindi's Tourism Industry.

Journal, Simon Hudson, Paul Hudson, and Graham A. Miller (2004). The Measurement of Service Quality in the Tour Operating Sector.

Journal, Lo Liang Kheng, Osman Mahamad, T. Ramayah \& Rahim Mohasab 
(2010). The Impact of Service Quality on Customer Loyalty: A Study of Banks in Penang, Malaysia. International Journal of Marketing Studies. Vol 2, No.2, November 2010. Hal 62.

Journal, HDV Garay (2010). Website Satisfaction Dan Commercial Friendships Sebagai Strategi Pemasaran Untuk Mencapai Keuntungan Jangka Panjang.

Journal, Baloglu (2002). Dimensions of Cusstomer Loyalty: separating friends from well wishers.

Journal, Van Riel Allard dan Janjaap Semeijn (2004). Online Travel Service Quality Toward Delighted and Loyal, Total Quality Management.

Journal, Cate Farral dan Marianne Lindsley (2008). Profesional English in Use Marketing.

Journal, Ben Delaney (2007). The Marketing Mix.

Skripsi. Handes Jalu atmanto (2009). Pengaruh Assurance yang dilakukan oleh PT.
Pakar Utama dalam Upaya Meningkatkan Kepercayaan bagi Biro Perjalanan Wisata.

Skripsi. Siti Aisyah Sucihati (2011). Peningkatan Kualitas Pelayanan pada Biro Perjalanan Wisata Ermi Tour Di Padang, Sumatera Barat.

E-book. Undang Undang No. 10 tahun 2009 Tentang Kepariwisataan.

E-book. Kotler \& Keller. 2012. Marketing Management. $14^{\text {th }}$ edition. Prentice Hall: USA

www.bandungtourism.com (diakses pada 2 Januari 2012)

www.budpar.go.id (diakses pada 26 Maret 2012)

www.budpar.go.id

www.wttc.com (diakses pada 3 April 2012)

www.wikipedia.org (diakses pada 3 april 2012) 
Desi Aryanti, Eeng Ahman, Dewi Pancawati

Tourism and Hospitality Essentials (THE) Journal, Vol.II, No.1, 2012 - 244 